\title{
ENCUESTA SOBRE EL TJUE COMO ACTOR DE CONSTITUCIONALIDAD
}

\author{
PRESENTACIÓN
}

Como nuestro atento lector bien sabe, las relaciones entre el Derecho nacional estatal y el Derecho de la Unión Europea se han convertido en uno de los temas clásicos de la doctrina constitucional; ya lo era por parte de otras disciplinas, como la internacional y la administrativa. El nivel de integración alcanzado por la actual Unión Europea ha movido a ello. Nuestra modesta Revista dedicó un temprano número 15 (año 2005) a analizar de forma monográfica el proceso de integración europea en el momento en el que se acababa de firmar, y estaba en trance de ratificación, el malogrado Tratado por el que se establecía una Constitución para Europa. Su no ratificación, sin embargo, no hizo que gran parte de los problemas políticos y jurídicos con los que nos encontramos la mayor parte de los europeos dejara de tratarse a nivel, ya no de los Estados, sino de la Unión Europea; y sobre todo que el proceso de integración y los conflictos inherentes a tal proceso no dejaran de cobrar interés para gran parte de la doctrina; así se explica que otro de nuestros monográficos —el n. 31 (1er semestre de 2013)—, que dedicamos de nuevo al proceso de integración política de Europa, debiéramos desdoblarlo con un segundo monográfico (n. ${ }^{\circ} 32$ ). Constatamos que eran muchos los constitucionalistas seniors y más jóvenes los que mostraban su interés por remitirnos colaboraciones sobre esta temática, ofreciendo todos artículos de muy meritorio nivel.

En cualquier caso, en el Consejo de Redacción de la Revista cobramos conciencia que quizá uno de los mayores avances en el proceso de constitucionalización de la integración europea fue la aprobación de la Carta de Derechos Fundamentales de la Unión Europea y la inserción de la misma en los Tratados. El Tribunal de Justicia de la Unión Europea — que históricamente ha desplegado un papel central como motor de la integración - tuvo así un documento que aplicar e interpretar, que condensaba uno de los elementos básicos de todo orden constitucional: los derechos fundamentales. Su particular relación con los tribunales nacionales y particularmente con los Tribunales Constitucionales de los Estados miembros a través de la cuestión prejudicial nos parece que puede dar 
márgenes a poder concebir tal tribunal como motor no ya, o no sólo, de la integración, sino de la integración constitucional de Europa.

Las relaciones de cooperación entabladas por los supremos intérpretes constitucionales de cada Estado miembro, empezando por el alemán, que plantearon cuestiones prejudiciales, nos introducen en un nuevo escenario; el famoso caso Melloni en España puede ser un buen ejemplo de ello. A quienes impulsamos Teoría y Realidad Constitucional nos ha parecido, en consecuencia, que todo ello justifica con creces dedicar a esta temática el presente número monográfico y analizar, por un lado, esta nueva configuración del Tribunal de Justicia de la Unión Europea y, por otro, la nueva realidad de cooperación entre Tribunales Constitucionales, el Tribunal de Justicia de la Unión Europea y el Tribunal Europeo de Derechos Humano; todo ello con vistas a crear un nuevo espacio de protección y garantía de los derechos más allá del Estado.

A tal fin, y como es costumbre en nuestra Revista, abrimos el presente número con una encuesta en la que catedráticos de nuestra especialidad y también de Derecho Internacional se pronuncian sobre una serie de cuestiones de esta materia que, como siempre, son en realidad, una excusa para que con toda libertad puedan ofrecernos sus reflexiones sobre tan relevante materia. Sin duda, nuestros lectores valorarán bien la alta finura con que los encuestados desarrollan sus respuestas.

\section{CUESTIONES}

1. El Tribunal Constitucional ha planteado en el caso Melloni su primera cuestión prejudicial ante el Tribunal de Justicia de la Unión Europea (TJUE), mediante el Auto 86/2011. ¿Qué comentarios nos puede hacer sobre esta actuación del Tribunal Constitucional?

2. En relación al mismo caso, ¿qué nos quiere decir sobre la respuesta del TJUE y acerca de la decisión final tomada por el Tribunal Constitucional (STC 26/2014), con tres votos particulares?

3. A la vista de esta primera experiencia, ¿considera que "está en la lógica de las cosas» que los Tribunales Constitucionales se conviertan, merced al planteamiento de estas cuestiones prejudiciales, en «clientes habituales» del TJUE?

4. El Tribunal Constitucional Federal Alemán, tradicionalmente defensor de la soberania estatal y de la identidad constitucional de los Estados, ha matizado dicha posición al plantear cuestión prejudicial en el caso del Banco Central Europeo. ¿Querría hacernos algún comentario sobre este caso y, especialmente, sobre los efectos de la relación de cooperación de los Tribunales Constitucionales con el TJUE sobre el futuro de la identidad constitucional de los Estados?

5. A la vista de lo anterior, ¿en qué posición quedan a su entender los Tribunales Constitucionales de los Estados miembros? ¿Y el Tribunal Europeo de Derechos Humanos? 
6. ¿Considera que sería conveniente reformar la Constitución para recoger expresamente la participación de España en la UE y las consecuencias que derivan de ella?

7. Sin perjuicio de lo anterior, a la vista de la dimensión de la Carta de derechos fundamentales y de la categoría de "la ciudadanía de la Unión» ¿estima que la Unión al ser garante de los derechos fundamentales avanza efectivamente en la creación de un espacio común de protección de los derechos? ¿Ha incorporado en su estructura —el TJUE incluido - un factor de expansividad competencial al que será muy difícil poner otro limite que el que autoadapten el TJUE y las restantes instituciones de la propia UE? ¿El TJUE se ha convertido en un factor de la constitucionalidad de los Estados miembros?

\section{ENCUESTADOS}

FRANCISCO BALAGUER CALLEJÓN, Catedrático de Derecho Constitucional, Universidad de Granada.

RAFAEL BUSTOS GISBERT, Catedrático de Derecho Constitucional (A), Universidad de Salamanca.

ASCENSIÓN ELVIRA PERALES, Catedrática de Derecho Constitucional (A), Universidad Carlos III.

JOSÉ MARTÍN Y PÉREZ DE NANCLARES, Catedrático de Derecho Internacional Público, Universidad de Salamanca ${ }^{1}$.

JAVIER MATÍA PORTILLA, Catedrático de Derecho Constitucional, Universidad de Valladolid.

JUAN LUIS REQUEJO PAGÉS, Letrado del Tribunal de Justicia de la Unión Europea.

\section{RESPUESTAS}

1. El Tribunal Constitucional ha planteado en el caso Melloni su primera cuestión prejudicial ante el Tribunal de Justicia de la Unión Europea (TJUE), mediante el Auto 86/2011. ¿Qué comentarios nos puede hacer sobre esta actuación del Tribunal Constitucional?

\section{FRANCISCO BALAGUER CALLEJÓN}

El ATC 86/2011 supuso una novedad importante en relación con la posible integración del Derecho europeo en el parámetro de constitucionalidad, algo que

1 Actualmente es Jefe de la Asesoría Jurídica Internacional del Ministerio de Asuntos Exteriores y de Cooperación. Las opiniones vertidas en esta encuesta lo son a título personal del autor y en modo alguno resultan atribuibles al Ministerio para el que actualmente trabaja. 
personalmente he defendido desde hace mucho tiempo. Por primera vez en ese Auto 86/2011, el Tribunal Constitucional admitió que el Derecho europeo puede integrar el canon de control de constitucionalidad, al indicar en su FJ 4.b) que: «En el presente recurso de amparo este Tribunal se enfrenta a un problema cuya solución depende, en gran parte, de la interpretación y de la validez de las disposiciones relevantes de la Decisión Marco 2002/584/JAI, del Consejo, de 13 de junio, así como de la interpretación del artículo 53 CDFUE y de las consecuencias que se deriven de esta disposición» ya que «el canon de control que debemos aplicar (...) ha de ser integrado a partir, entre otras, de las normas de Derecho de la Unión Europea que protegen los correspondientes derechos fundamentales, así como de las que regulan la orden europea de detención y entrega». Era previsible, por tanto, un cambio sustantivo de la doctrina seguida hasta ahora por el Tribunal Constitucional.

\section{RAFAEL BUSTOS GISBERT}

Desde un punto de vista general, el planteamiento de la cuestión prejudicial por parte del Tribunal Constitucional (en adelante, TC) debe ser valorado muy positivamente. Es más, lo que debería sorprender y provocar reflexión es que haya tardado 25 años en plantear una cuestión prejudicial. Esta «resistencia» a plantear la cuestión, que no es exclusiva de España, ha sido afortunadamente vencida y ha de ser bienvenida sobre todo si ahondamos en cuáles eran los posibles motivos por los cuáles la jurisdicción constitucional renunciaba al ejercicio de la cuestión prejudicial. Una primera explicación podría radicar en, como destilan algunas de las sentencias constitucionales en las que el Derecho de la UE estaba en cierta medida implicado, considerar que el Derecho de la Unión era algo ajeno al ordenamiento jurídico constitucional y, por tanto, podía ser objeto de atención por el TC solo de manera absolutamente instrumental. En tal sentido, excepto en los casos de control previo de constitucionalidad de tratados de la UE, el TC considera al Derecho de la UE como un derecho «ajeno» al Derecho que había de aplicar lo que, evidentemente, excluía la posibilidad de usar la cuestión prejudicial en cuanto que ni la interpretación ni la validez de ese Derecho era relevante para la decisión del fondo de los asuntos sometidos a su consideración. Este planteamiento habría venido perdiendo fuerza con el paso de los años en la medida en que la realidad de los conflictos suscitados ante el TC ponía de manifiesto la importancia de que éste en sus resoluciones fuera respetuoso también con el Derecho de la UE y con su eficacia, lo que, obviamente, abría el camino a que planteara sus dudas ante el TJUE. Un segundo motivo, a nuestro juicio más importante, explicaría no solo la ausencia de cuestiones prejudiciales procedentes de la jurisdicción constitucional española, sino también de la inmensa mayoría de los Tribunales Constitucionales europeos. Coincido en este punto con gran parte de la doctrina europea que se ha ocupado de estos temas en que los Tribunales 
Constitucionales nacionales no utilizaban la Cuestión Prejudicial en cuanto ello podía poner en riesgo su posición institucional. Esto es, plantear una cuestión prejudicial supone asumir que respecto a la pregunta suscitada la última palabra la tendría el TJUE y no el propio Tribunal que la plantea. Usar la cuestión, presupone que se está dispuesto a aceptar la respuesta. Y con ello se genera una suerte de relación vertical entre el tribunal que cuestiona y el cuestionado. Relación en la que el TC asumiría su inferioridad respecto al TJUE. En fin, plantear la cuestión prejudicial sería tanto como asumir que hay materias constitucionales en las que la última palabra la tendría el Tribunal de la UE y no el Tribunal Constitucional. A nadie se le escapa que esta asunción no es sencilla para un órgano que es el supremo intérprete de la norma constitucional. Más allá de que esos miedos estuvieran justificados en la teoría y en la práctica; lo cierto es que la ausencia de planteamientos de cuestiones prejudiciales por parte de los Tribunales Constitucionales nacionales (con la excepción de Bélgica) constituía una anomalía en la medida en que en la construcción pretoriana del Derecho de la UE a través del diálogo entre TJUE y jueces nacionales faltaba la esencial contribución de los Tribunales Constitucionales en cuanto garantes de la norma suprema nacional, en general, y de los derechos fundamentales, en particular.

Desde un punto de vista procedimental, la avocación al Pleno de la decisión sobre el planteamiento de la cuestión también nos parece acertada en la medida en que la importancia de tal decisión aconseja que sea este y no las Salas las que han de plantearla.

Sea pues bienvenido el Tribunal Constitucional español al diálogo directo con el TJUE.

Si entramos en la valoración en concreto de la cuestión prejudicial planteada la valoración ha de ser un poco más crítica. En tal sentido parece que tiene sentido el Voto Particular planteado por el magistrado Pérez Tremps respecto a la impertinencia de su planteamiento pues, sobre todo, tengo mis dudas de que la norma aplicable, ratione temporis, al caso fuera la versión de la Decisión Marco sobre la que se duda. Nótese en especial que en su respuesta el TJUE no va a entrar a valorar ese concreto aspecto. Creo que, efectivamente, hubiera tenido más sentido plantearla cuando así lo solicitó el citado magistrado en su voto particular a la STC 199/2009.

\section{ASCENSIÓN ELVIRA PERALES}

Mucho se ha escrito sobre ese Auto, seguramente más por ser el primero que planteaba el Tribunal Constitucional que por su interés intrínseco.

En mi opinión, dos son los comentarios posibles:

Uno, con carácter general, para resaltar que la presentación de cuestiones prejudiciales por parte del TC no solo es una práctica aceptable sino incluso conveniente y entraría dentro de la normalización de este tipo de prácticas por parte 
de otros tribunales constitucionales u órganos equivalentes europeos, pues, por mucho que su función se centre en el ámbito interno, la expansión del Derecho de la UE hace imposible una separación absoluta entre el mero control de constitucionalidad y la aplicación del Derecho de la Unión, más difícil aún si, como es nuestro caso, existe el recurso de amparo. Por otra parte, con el planteamiento de la cuestión el TC hace patente la virtualidad de este instrumento, su encaje en la práctica judicial española y puede servir de acicate para animar a los órganos jurisdiccionales ordinarios reticentes (o apocados) a dirigirse al TJUE.

Otro, sobre el planteamiento de este concreto recurso. En este sentido, más parece que se ha buscado esta vía como medio para cambiar la jurisprudencia previa sobre la materia que como vía para conocer la interpretación del TJUE, pues, en el primer caso, hubiera sido más razonable haber planteado una cuestión con anterioridad al haberse suscitados casos similares, en concreto el de la STC 199/2009. Sin embargo, conviene señalar algún aspecto que pudo incidir en la diferencia entre un supuesto y otro: uno, que en la última sentencia citada aún no gozaba de plenos efectos jurídicos la CDFUE (la STC es de septiembre y fue en noviembre de 2009 cuando entró en vigor el Tratado de Lisboa), de manera que cabría entender que existía después una mayor confianza en la defensa de los derechos por parte del TJUE al contar con un instrumento específico propio como es la Carta; otro, que poco a poco los tribunales constitucionales u órganos afines de distintos Estados habían comenzado a plantear cuestiones prejudiciales al TJUE, lo que significaba que la separación estricta entre justicia constitucional y Derecho europeo que venían propugnando los tribunales constitucionales se había quebrado, lo cual resultaba inevitable dado que el Derecho de la Unión cada vez penetra en más ramas del Derecho (a pesar de que luego interpretativamente siga manteniéndose la división).

Que el motivo del planteamiento fuera permitir un cambio con respecto a la doctrina anterior se ve corroborado por la posterior sentencia de nuestro Tribunal Constitucional.

\section{JOSÉ MARTÍN Y PÉREZ DE NANCLARES}

De entrada, el planteamiento de una cuestión prejudicial por parte del Tribunal Constitucional nos merece una valoración muy positiva en la medida en que rompe una inercia que nos parecía poco razonable. Celebramos, por tanto, que nuestro Tribunal Constitucional se haya decidido a seguir la senda marcada antes por otros Tribunales Constitucionales de Estados miembros de la UE y haga uso del mecanismo de cooperación judicial previsto en el artículo 267 TFUE. Se trata, sin duda, de un interesante instrumento que activa la imprescindible cooperación judicial institucionalizada entre los órganos jurisdiccionales nacionales y el TJUE. No debería ser, además, de otra manera, cuando el Tribunal Constitucional esté abordando un asunto en el que se plantee una duda sobre 
la interpretación de los tratados constitutivos de la UE o sobre la validez e interpretación de los actos adoptados por las instituciones de la Unión; el Tribunal Constitucional debería hacer uso en estos casos de la cuestión prejudicial con toda normalidad, siempre que de la disposición comunitaria en cuestión dependa la resolución del asunto del que esté conociendo y no pueda resolverse la referida duda conforme a la doctrina fijada al respecto por el Tribunal de Justicia, en especial la doctrina del 'acto claro'.

Más dudas nos plantea, sin embargo, la cuestión de si nuestro Tribunal Constitucional ha acertado a la hora de escoger el mejor asunto posible para romper el hielo de esta necesaria cooperación judicial institucionalizada con el TJUE. En verdad, a nuestro entender, ni el Tribunal Constitucional eligió el caso más adecuado ni el TJUE aprovechó el asunto en todas sus posibilidades para reforzar el 'diálogo judicial' (material) entre ambos tribunales en materia de derechos humanos. Con todo, bienvenida sea la decisión de plantear cuestión prejudicial.

\section{JAVIER MATÍA PORTILLA}

El Auto merece una valoración crítica por diversas razones que atañen a la justicia material, a la dogmática jurídica y a la estrategia seguida por el alto Tribunal.

La crítica primera, y más evidente, es porque la demanda de amparo debería haber sido inadmitida o, cuando menos, en atención a la discutible jurisprudencia previa del Alto Tribunal (SSTC 91/2000 y, especialmente, 199/2009), desestimada. En efecto ni se acredita en el recurso que exista indefensión material alguna que mereciera ser reparada ni, aunque se hubiera producido la misma, podría ser amparado quién se sitúa, voluntariamente, en ella. En definitiva, existían razones jurídicas suficientes para desestimar, sin más trámites, las quejas del recurrente.

La segunda crítica que podría formularse al ATC 86/2011 es que un Tribunal Constitucional no aplica, por definición, Derecho de la Unión, por lo que no se encuentra en el supuesto previsto en el artículo 267 TFUE. Desarrollamos esta objeción, con más detalle, en la pregunta tercera de la presente encuesta.

Y nos queda aludir a la tercera discrepancia, que hemos denominado estratégica. Los Magistrados del Tribunal Constitucional han planteado una cuestión prejudicial al socaire de una demanda de amparo que podría ser calificada de temeraria en su formulación. No debería causarles sorpresa que el Tribunal de Justicia de la Unión Europea realizara una interpretación estricta de la Decisión Marco y restrictiva de las facultades de los tribunales nacionales en un asunto como el planteado en la Sentencia de 26 de febrero de 2013. Soy consciente de que la respuesta dada por el Tribunal de Justicia de la Unión Europea se realiza interpretando normas, y no resolviendo casos concretos, pero es legítimo pensar que si el supuesto fáctico subyacente planteara otras problemáticas más relevantes (el encausado tuvo un infarto un día antes del juicio, hubiera constancia 
expresa de la falta de diligencia del letrado defensor, etc.) la respuesta del Tribunal habría sido, quizás, más matizada.

Si los Magistrados del Tribunal Constitucional esperaban que el Tribunal de Justicia dijera lo que iba a decir, tenían que ser igualmente conscientes de que ello les situaba en una situación endemoniada. Solamente tenían dos posibilidades: o conceder un (sorprendente) amparo al recurrente, enfrentándose al Tribunal de Justicia, a la opinión pública y al sentido común, o denegar el amparo solicitado (lo que podría entenderse como una pérdida de autoridad dentro del país, y trasladar, además, una imagen negativa del proceso europeo de integración, que serviría no solamente para ampliar derechos, sino también, en su caso, para reducirlos). Este riesgo podría haber sido conjurado evitando la cuestión prejudicial y asumiendo ellos, directamente, el protagonismo que finalmente han tenido en la STC 26/2014, de 13 de febrero.

\section{JUAN LUIS REQUEJO PAGÉS}

La renuencia del Tribunal Constitucional a plantear una cuestión prejudicial (art. 267 TFUE) ha podido interpretarse en el pasado como el efecto de una insensibilidad imperdonable a la dimensión comunitaria del Derecho español. En mi opinión, sin embargo, esa insensibilidad venía impuesta por el alcance mismo de esa dimensión comunitaria, que en el ámbito de la jurisdicción constitucional no podía sino traducirse en la posición de principio adoptada en la STC 28/1991: el Derecho de la Unión no puede ser, en ningún caso, parámetro de validez constitucional de las normas nacionales.

Las cosas han cambiado de manera radical con el Tratado de Lisboa. En el año 2009 el proceso de integración ha experimentado un cambio de cualidad que ha hecho de la Unión algo más que el contexto normativo de un mercado. Presentándose como una respuesta de circunstancia al fracaso de la Constitución Europea, el Tratado de Lisboa abriga en su interior una potencialidad constituyente tan extraordinaria como inadvertida, cifrada en una Carta de Derechos con la que se ha introducido en el núcleo de los Tratados un universo de categorías y conceptos que ha de hacer imposible la continuidad del entendimiento meramente comunitario y mercantilista del Derecho de la Unión.

La Unión es ahora, en virtud de la Carta, una comunidad de derecho que no se conciben ya en función de las cuatro libertades económicas clásicas y a su servicio, sino como patrimonio jurídico de la persona, a la que la Unión, de acuerdo con el Preámbulo de la Carta, «[a]l instituir la ciudadanía de la Unión y crear un espacio de libertad, seguridad y justicia, sitúa [...] en el centro de su actuación». Ciertamente, el Tribunal de Justicia de la Unión ya había venido decantando un elenco de derechos fundamentales a partir de las «tradiciones constitucionales compartidas», pero con la Carta de Niza se ha constitucionalizado como Derecho positivo primario lo que hasta entonces había sido el producto más o menos 
voluntarista del activismo pretoriano del Tribunal de Justicia, propiciándose con ello un cambio de principio en la cualidad del ser propio de la Unión y, por consecuencia, en la condición misma de los ciudadanos nacionales, ahora también ciudadanos de la Unión en la medida en que son titulares, frente a ésta, de un estatuto jurídico equivalente al que antes sólo tenían frente a los Estados miembros; es decir, de un estatuto que comprende todas las manifestaciones posibles de su personalidad.

Al plantear su primera cuestión prejudicial con el ATC 86/2011, el Tribunal Constitucional no ha hecho otra cosa que ser consecuente ante el cambio de cualidad experimentado por el Derecho de la Unión con el Tratado de Lisboa, que ha hecho del Tribunal de Justicia una jurisdicción de derechos fundamentales, con cuanto ello significa en particular para nosotros por obra del artículo 10.2 CE. Es posible que, lastrado por la inercia que representan sesenta años de ejercicio de una jurisdicción centrada en la dimensión económica de la integración europea, el propio Tribunal de Justicia tarde aún en ser plenamente consciente de su nueva condición de garante de los derechos fundamentales asumidos por la Unión como Derecho propio y no como mera expresión de las tradiciones constitucionales compartidas. Sin embargo, ese cambio radical de cualidad no tardará en desplegar su lógica ineluctable, lo que desde la perspectiva española significa que los derechos fundamentales reconocidos por la Constitución cuentan ahora con un nuevo parámetro de integración de la validez de las normas nacionales (la Carta) y con un nuevo intérprete autorizado (el Tribunal de Justicia), al mismo nivel que el Convenio de Roma y el Tribunal de Estrasburgo, respectivamente.

Ello ha de suponer un cambio radical en las relaciones del Tribunal Constitucional con el Derecho de la Unión y, en particular, con el Tribunal de Justicia. En estas nuevas circunstancias el «autismo comunitario» no puede ya ser una opción para el Tribunal Constitucional. El Tribunal de Justicia está llamado a definir ex artículo 10.2 CE los derechos fundamentales garantizados por el Tribunal Constitucional, por lo que a éste sólo puede importarle, y mucho, a partir de ahora, lo que aquél haya de decir en su cometido como intérprete autorizado, y vinculante, de los derechos fundamentales comunitarios. Y ante esta verdadera, y muy seria, cesión de soberanía en uno de los ámbitos más sensibles y definitorios de nuestro sistema constitucional, el Tribunal Constitucional está obligado a propiciar, en lo posible, que la responsabilidad adquirida ad intra por el Tribunal de Justicia se traduzca en una interpretación de la Carta inspirada, cuando menos, en nuestra propia cultura constitucional de los derechos. El concepto de «identidad constitucional» ha de jugar aquí, seguramente, un papel fundamental.

Hoy por hoy, la cuestión prejudicial constituye el instrumento natural para la comunicación de las jurisdicciones constitucionales nacionales con el Tribunal de Justicia y, por tanto, el medio para invitar al Tribunal de Luxemburgo a un determinado entendimiento de los derechos. Anticiparse a la jurisprudencia del Tribunal de Justicia participando activamente en su definición es la única manera de asegurarse cierta influencia en un proceso que ya no está en las solas manos de 
los Tribunales nacionales. Por eso el ATC 86/2011 ha sido, sobre todo, una iniciativa inteligente. Situar, por vez primera, al Tribunal de Justicia en la tesitura de definirse sobre cuestiones tan relevantes como el contenido del derecho a un proceso con todas las garantías y, antes aún, sobre el principio de garantía de la «mayor protección», suponía garantizarse que, fuera cual fuese la respuesta del Tribunal de Luxemburgo, ésta no dejaría de estar marcada por la perspectiva que ha dado a esas cuestiones el planteamiento del Tribunal Constitucional. Siquiera sea sólo porque quien pregunta contribuye en buena medida a la definición de la respuesta, el Tribunal Constitucional está desde ahora obligado, en beneficio de la garantía de nuestra identidad constitucional, a requerir del Tribunal de Justicia una definición de los derechos de la Unión que se acomode, en el mayor grado de lo posible, al espíritu de la Constitución. La cuestión prejudicial adquiere así una dimensión inédita y en absoluto irrelevante, como en el pasado, para el Tribunal Constitucional.

2. En relación al mismo caso, ¿qué nos quiere decir sobre la respuesta del TJUE y acerca de la decisión final tomada por el Tribunal Constitucional (STC 26/2014), con tres votos particulares?

\section{FRANCISCO BALAGUER CALLEJÓN}

Desgraciadamente la respuesta del TJUE no estuvo a la altura de las expectativas generadas por el ATC 86/2011, porque realizó una interpretación del artículo 53 de la Carta de los Derechos Fundamentales de la Unión Europea que conduce a desactivar la función que ese precepto podía cumplir como instrumento de articulación del ordenamiento europeo y los ordenamientos internos en relación con los derechos fundamentales. El TJUE marca una frontera insalvable al establecer que «el artículo 53 de la Carta confirma que, cuando un acto del Derecho de la Unión requiere medidas nacionales para su ejecución, las autoridades y tribunales nacionales siguen estando facultados para aplicar estándares nacionales de protección de los derechos fundamentales, siempre que esa aplicación no afecte al nivel de protección previsto por la Carta, según su interpretación por el Tribunal de Justicia, ni a la primacía, la unidad y la efectividad del Derecho de la Unión». El TJUE podía haber resuelto la cuestión centrándose en la naturaleza del derecho concreto afectado en lugar de establecer criterios generales que reducen las posibilidades de relación dialéctica e integradora entre los ordenamientos.

Por lo que se refiere a la Sentencia 26/2014, de 13 de febrero, se puede decir que se mantiene en la misma línea deficiente de la jurisprudencia anterior ya que en ella se resuelve la cuestión de fondo apelando de nuevo al Derecho europeo como criterio interpretativo, lo que nos conduce al art. 10.2 CE y no a su 
aplicación directa como parte del parámetro de constitucionalidad. En mi opinión, los votos particulares son más sólidos que la decisión del Tribunal y es de desear que el criterio mantenido en alguno de ellos se convierta en el futuro en la doctrina mayoritaria, con un sentido más europeísta de la jurisprudencia del Tribunal Constitucional y una mayor atención a la realidad de la inevitable relación dialéctica entre el ordenamiento europeo y el ordenamiento interno, que exige más integración y menos fronteras artificiales.

\section{RAFAEL BUSTOS GISBERT}

Respecto a la decisión del TJUE a las cuestiones suscitadas mi impresión es ambivalente. Por una parte, coincido en el fondo del asunto pues la respuesta es coherente con la lógica del Derecho de la UE. Por la otra, me parece que la forma es insatisfactoria.

Desde el primer punto de vista, es cierto que la respuesta se sitúa en la ortodoxia de los principios reguladores de las relaciones entre el ordenamiento nacional y el de la Unión. El principio de primacía exige la eliminación de todo obstáculo interno, incluso de rango constitucional, que impida la eficacia de las normas del Derecho de la Unión. Igualmente, desde la perspectiva del principio de autonomía del ordenamiento jurídico europeo, resulta claro que solo pueden aceptarse interpretaciones nacionales que no pongan en peligro la unidad en la aplicación del Derecho de la UE. De ahí, por tanto, deriva que cualquier mayor protección de los derechos derivada del ordenamiento nacional solo será aceptable en cuanto no obstaculice ni la aplicación de la Decisión Marco, ni su interpretación uniforme. Lo que el TC de alguna manera proponía era oponer un obstáculo interno (la configuración jurisprudencial del art. 24 ad extra) a la plena aplicación de la Decisión Marco (que no preveía esa excepción) rompiendo la uniformidad en su interpretación (puesto que su eficacia final dependería de que los ordenamientos nacionales negaran una entrega en función de la configuración de sus derechos fundamentales) y, sobre todo, el principio de mutua confianza inspirador de toda la regulación. Por tanto, nada que oponer desde el punto de vista del fondo de la cuestión.

Sin embargo, desde la perspectiva de la «forma» en la que el TJUE responde al Tribunal Constitucional creo que se podrían hacer algunas críticas. En primer lugar, creo que el TJUE en ningún momento demuestra lo que la doctrina (véanse por todos el trabajo de Aida Torres, Conflicts of Rights in the European Union, 2009) ha llamado la «deferencia» (comity) necesaria para establecer diálogos judiciales con altas instancias de control de constitucionalidad sobre materias en las que pueden producirse colisiones relevantes. Esta idea de deferencia exige que se atiendan con calma y profusión argumentativa las razones esgrimidas por el otro actor judicial con el que se dialoga y no se adopten posiciones de superioridad o de imposición de la propia opinión sino más bien de respeto y búsqueda de consenso. 
La respuesta del TJUE era, en este caso, una buena oportunidad para demostrar deferencia hacia un Tribunal Constitucional. Sin embargo, la resolución trata el asunto y al proponente como si de cualquier órgano judicial se tratara. Y ello resulta especialmente criticable si tenemos en cuenta los dos motivos siguientes.

Efectivamente, la sentencia del TJUE parece criticable, en segundo lugar, por lo escueto de su razonamiento en un asunto que merecía mucho más desarrollo. La cuestión planteada por el TC suponía la primera ocasión en la que el TJUE tenía que pronunciarse sobre los artículos 52.4 y 53 de la CDFUE que son, sin duda, de los más importantes y complejos de todo el texto. En concreto, la cuestión planteaba el problema básico de cuáles son las relaciones entre un derecho fundamental reconocido en la Carta y otro reconocido en un texto constitucional nacional cuando éste confiere una mayor protección que aquél. Examinar dicho precepto requería algo más que dos escuetos fundamentos jurídicos reiterativos de la configuración general del principio de primacía. Además esta parquedad en la argumentación comienza a resultar preocupante en la práctica del TJUE, especialmente en los casos más complejos.

En tercer lugar, la deferencia y la mayor motivación resultaban especialmente importantes si tenemos en cuenta lo que en el fondo estaba decidiendo el TJUE. En su resolución este tribunal está ordenando al TC que entregue al sr. Melloni incluso si con ello ha de aplicar un estándar de protección de los derechos inferior al que hasta ahora ha aplicado. En definitiva, el TJUE está ordenando a una instancia de defensa de la Constitución que reduzca la protección de los derechos hasta entonces reconocida. Está, si se quiere decir de otro modo, obligando al Tribunal Constitucional a cambiar su jurisprudencia de modo que lo que antes era inconstitucional por lesivo del derecho contenido en el artículo 24 de la constitución nacional, ahora habrá de considerarlo conforme con ella. Para ordenar algo tan grave a una instancia de control de constitucionalidad nacional, sinceramente, creo que el TJUE debería haber argumentado mucho más su resolución (y con ello haber introducido matices relevantes para el caso) y haber mostrado mucha más deferencia a una instancia nacional de control de constitucionalidad que se animaba, por primera vez, a plantear una cuestión prejudicial y con ello aceptaba sin ambages que en ese concreto tema, la decisión última en una cuestión de derechos fundamentales se situaba en el TJUE y no en las instancias nacionales. Con ello, además, podría haber clarificado a los aplicadores del Derecho el modo en que actúa la Carta y cuáles son los límites que efectivamente impone, sobre todo, al Derecho derivado.

Respecto a la solución finalmente conferida al asunto con la STC 26/2014 creo que el TC podría haber interpretado el ordenamiento constitucional español (y el de la UE) de manera más acorde con el caso. El TC reitera, a mi juicio, un error que ya estaba presente en su jurisprudencia anterior (incluso a la entrada en vigor de la CDFUE) y que el Legislador orgánico también cometió al ratificar el Tratado de Lisboa. Como señalamos en este mismo número, la CDFUE no es exactamente un tratado de derechos, sino más bien el bill of rights de la UE. No es lo mismo. Está en vigor en España a través del mecanismo del art. 93 de la 
Constitución y, por tanto, genera el efecto de desplazar toda norma contraria. Pero el TC ha declarado (y el legislador orgánico lo reitera) que es un tratado de derechos con la eficacia propia del art. 10.2 CE en sus relaciones con los derechos contenidos en la Constitución. Con este punto de partida al TC solo le quedaba un camino si deseaba cumplir con la sentencia del TJUE: reinterpretar globalmente el art. 24 en su dimensión ad extra. Y es lo que hace.

El problema es que, como en el fondo creo que señalan los Votos Particulares, la solución no tiene mucho sentido. Reducir los derechos de las personas que han de ser entregadas a terceros Estados puede tener sentido en el ámbito de la UE pues existen normas comunes (de la Unión y derivadas de los mínimos establecidos en el $\mathrm{CEDH}$ ) y, sobre todo, porque existe un principio de confianza mutua en virtud del cual los Estados miembros asumieron que la protección procesal de los derechos en el resto de Estados era equivalente a la dispensada por sus propios ordenamientos (principio de confianza mutua). Pero ni esas normas comunes, ni esa confianza mutua existen respecto a terceros Estados no miembros de la UE. Dicho en otros términos, tiene pleno sentido que entreguemos a alguien condenado en ausencia para ser juzgado, o que se cumpla su condena en Italia, sin pedir ulteriores garantías porque es miembro de la UE, del CEDH y porque confiamos en su orden procesal penal. Y del mismo modo tiene pleno sentido que no entreguemos a alguien en las mismas circunstancias cuando lo es a un Estado que no pertenece a la UE y con el que no hemos expresado ninguna confianza en su sistema procesal.

La solución más razonable debería, pues, haber aplicado la sentencia del TJUE en sus estrictos términos. La Decisión Marco desplaza el derecho interno, incluido el de los derechos fundamentales, en su ámbito de aplicación. No más allá. Esta es una solución razonable porque ese desplazamiento no produce que el recurrente carezca de derechos, sino que tendrá siempre los derivados de la CDFUE y los derivados del CEDH. El desplazamiento se produce por acción del art. 93 CE unido al principio de primacía. Pero no significa la nulidad o la necesidad de anular las normas internas que pueden ser aplicables a otros tipos de situaciones. De este modo bastaría con que el TC hubiera acordado que no había violación de los derechos del sr. Melloni, ni de cualquier otro ciudadano que fuera a ser entregado a un Estado miembro del sistema de la orden de entrega, en cuanto tales derechos están garantizados de manera equivalente por la CDFUE, por el CEDH y por la Constitución del Estado en el que va a ser juzgado o a cumplir su condena. En el resto de casos, la anterior doctrina podría seguir siendo de aplicación porque no entra en juego el Derecho de la UE. Esto supone aceptar la existencia de dos regímenes jurídicos distintos. Uno más laxo para la entrega en el ámbito de la UE y otro más exigente para la entrega fuera del ámbito de la UE. Precisamente, en eso consiste la UE en la convivencia de regímenes jurídicos diferentes en función del ámbito de aplicación de cada uno.

El resultado sin embargo ha sido otro y ha consistido en una reducción generalizada y sin matizaciones del ámbito de protección del art. 24 ad extra sin que realmente eso fuera una exigencia de la Sentencia del TJUE. 


\section{ASCENSIÓN ELVIRA PERALES}

La respuesta del TJUE es la respuesta lógica a la propia existencia de la denominada 'euroorden' y a los principios del Derecho de la UE, si bien podría entenderse que 'rebaja' el alcance del art. 53 CDFUE. Sin embargo, en un ámbito como el de la Unión Europea en el que se tiende a la armonización de los Derechos internos y a la cooperación entre Estados, es obvio que la búsqueda de mecanismos y políticas comunes han de conducir al rechazo de posiciones maximalistas si estas impiden el logro de la consecución de unos fines comunes. Si en determinados supuestos cabe decantarse por la máxima protección estatal frente al estándar común, en otros casos no podrán admitirse esas diferencias pues implicarían el fracaso de políticas europeas. Como es habitual en la Unión, todos han de ceder para que no pierda ninguno. Otro factor clave es la comunidad de Derecho que se predica de los integrantes de la Unión y que reflejó el TEDH en el conocido asunto Bosphorus y que ha de conducir a que — salvo que se tenga conocimiento expreso de vulneraciones de derechos por parte de un Estado- se presume que todos los Estados miembros aplican unos criterios similares en la defensa de los derechos y que todos respetan el Estado de Derecho. El automatismo, no obstante, no será absoluto, sino que admitirá excepciones en aquellos casos en los que la entrega implique una probable vulneración de derechos de los afectados, tal como se recoge en el caso Aranyosi y Caldararu (C-404/15 y C-659/15 PPU), donde se indica que no procederá la entrega cuando las condiciones de detención en el Estado miembro emisor puedan dar lugar a un trato inhumano o degradante, lo que pone de relieve que la imposición de una aplicación sin matices del Derecho europeo solo es posible partiendo del presupuesto de la garantía de los derechos por parte de todos los Estados implicados.

Por otro lado, el TJUE se ha pronunciado en otras ocasiones sobre la euroorden, lo que le ha permitido ir perfilando el alcance y los límites posibles: así en el asunto Dworzecki (C-108/16 PPU), en el que considera que no se han dado las condiciones para presumir que se habían dado las garantías pertinentes relativas a la citación; asunto Lanigan (C-237/15 PPU) con respecto al cumplimiento de los plazos y la posibilidad del mantenimiento de la detención; asunto Jeremy $F$. (C-168/13 PPU) sobre criterios aplicables en supuestos de concurrencia de órdenes de detención y entrega.

Con todo, la STJUE en el asunto Melloni no es un caso más entre los pronunciamientos sobre la euroorden sino que se ha convertido en uno de los casos paradigmáticos de su doctrina sobre derechos fundamentales en la UE, lo que, recordemos, supone una obligación de interpretación igual para todos los órganos jurisdiccionales de la Unión Europea. En concreto el párrafo 60 de la Sentencia afirma: «Es cierto que el artículo 53 de la Carta confirma que, cuando un acto del Derecho de la Unión requiere medidas nacionales para su ejecución, las autoridades y tribunales nacionales siguen estando facultados para aplicar estándares nacionales de protección de los derechos fundamentales, siempre que esa aplicación no afecte 
al nivel de protección previsto por la Carta, según su interpretación por el Tribunal de Justicia, ni a la primacía, la unidad y la efectividad del Derecho de la Unión», por lo que se ha convertido en uno de los mandamientos en torno a la eficacia de los derechos fundamentales en la Unión Europea. Con esta Sentencia el TJUE ha vuelto a resaltar el principio de primacía del Derecho de la Unión que se vería en entredicho si el art. 53 CDFUE se interpretara de con un criterio maximalista, a la vez que incide en que la propia existencia de la Carta y el valor jurídicos de que se le dota suponen una garantía para la eficacia de los derechos que no precisa de una interpretación más favorable si de esa forma se pone en juego la citada primacía. En este punto hay que tener en cuenta que, de otro modo, la disparidad de normas procesales podría conducir a vaciar la eficacia de la orden europea de detención.

La decisión del asunto Melloni ha alcanzado, pues, una dimensión que seguramente no esperaban sus promotores, quienes sin duda la enfocaban desde un ángulo puramente interno.

El Tribunal Constitucional, como ya apuntaba en la pregunta anterior, se sirve de la resolución del TJUE para cambiar su previa doctrina, citando igualmente Sentencias del TEDH, con una argumentación basada más en el art. 10.2 $\mathrm{CE}$ en relación con el art. $24 \mathrm{CE}$ que en las relaciones Derecho UE-Derecho interno. El pronunciamiento del TJUE, pues, podría decirse que es la 'coartada' que emplea el TC para modificar su doctrina anterior, que esta era la intención lo pone bien de relieve la propia argumentación reflejada en el antepenúltimo párrafo del FJ 4. La cuestión remite a que, como decía el voto particular del magistrado Pérez Tremps que acompañaba al Auto de presentación de la cuestión prejudicial, esta no resultaba apropiada y hubiera bastado que el Tribunal Constitucional cambiara su doctrina para lo que podía apoyarse, como luego hizo, en diferentes sentencias del TEDH y del TJUE. El Tribunal Constitucional después de plantear la cuestión prejudicial, lo que parecía abrir la puerta a establecer una mayor fluidez en la relación entre tribunales, vuelve a atrincherarse en su argumentación en torno a la separación de las funciones del Tribunal Constitucional con respecto al Derecho europeo, soslayando que este último es también Derecho aplicable y al que están sometidos todos los órganos del Estado.

Los votos particulares formulados por las magistradas Sras. Asua y Roca subrayan la cortedad de la argumentación ofrecida y la separación en la argumentación de la resolución del TJUE para abordar la cuestión como un asunto puramente interno, esquivando la ocasión para poner de relieve las necesarias (e ineludibles) relaciones entre el Derecho de la Unión y el Derecho interno. Remito a esos votos, en particular al segundo, para abordar las carencias de la Sentencia 26/2014. No deja de llamar la atención que quien fue ponente de la Sentencia, la Sra. Roca, a su vez formule un voto particular a la misma.

El voto del Sr. Ollero discurre por otros derroteros: por una parte, atribuyendo el cambio de doctrina también a terceros Estados (lo que no es el caso), pues incluso dentro de la Unión si se tuviera conocimiento de vulneración de derechos por parte de países miembros podría dar lugar a la no ejecución de una 
orden de entrega. Por otra, lamenta que nuestro Tribunal Constitucional no haya aprovechado la ocasión para animar a la Unión Europea a suscribir el CEDH, deseo que resulta fuera de lugar.

\section{JOSÉ MARTÍN Y PÉREZ DE NANCLARES}

En nuestra opinión, desde el punto de vista material, el TJUE pudo haber sacado bastante más partido al asunto, en especial en relación con los artículos 51 y 53 de la Carta de Derechos Fundamentales de la UE. Y, desde el punto de vista formal, el TJUE probablemente pudo ser también en la concreta formulación de su sentencia algo más deferente con el Tribunal Constitucional, que a la postre había adoptado la importante decisión de hacer uso (por primera vez) del mecanismo de la cuestión prejudicial.

Por lo que específicamente respecta a la sentencia final del Tribunal Constitucional, nuestro Alto Tribunal ha recurrido al artículo 10.2 de la Constitución para superar la contradicción que existía entre su jurisprudencia anterior y la del TJUE (STC 26/2014, de 13 de febrero). Pervive, en todo caso, cierta incertidumbre en relación con la referencia al artículo 53 de la Carta (entonces art. II-103 del Tratado Constitucional) que, de manera no muy precisa (y probablemente desafortunada), recogía la Declaración 1/2004; ello a pesar de que la Sentencia del Tribunal Constitucional se refiere de manera amplia a aquella Declaración.

No pueden pasar desapercibidos tampoco los tres votos particulares. A nuestro juicio, destaca a este respecto el fundado desacuerdo que muestra la vicepresidenta Adela Asúa a la hora de considerar el referido artículo 10.2 como fundamento único para justificar la eficacia de los derechos reconocidos en el ámbito de la UE dentro del ordenamiento jurídico español. También resulta notable la crítica de la magistrada Encarnación Roca a la falta de asunción clara por el Tribunal Constitucional de su papel como juez comunitario. A nuestro entender, la decisión final tomada por el Tribunal Constitucional plantea, en efecto, algunas dudas. Fundarse únicamente en el artículo 10.2 de la Constitución para resolver la cuestión planteada en el asunto Melloni supone haber perdido una oportunidad de oro para, desarrollando la doctrina establecida en la Declaración 1/2004, clarificar con mayor precisión y acierto la concreta relación jurisprudencial multinivel que se plantea en el espacio judicial europeo entre el TJUE y el Tribunal Constitucional en materia de derechos fundamentales. Igualmente, una clarificación más explícita del papel de nuestro Alto Tribunal como juez comunitario tampoco habría estado de más.

\section{JAVIER MATÍA PORTILLA}

Es de justicia señalar, y con ello entramos en el examen de la STC 26/2014, que si algo acredita el Tribunal Constitucional en esta resolución, es que ha 
sabido salir con bien de esa situación incómoda en la que él mismo se había situado. El alto Tribunal reivindica su función de intérprete máximo de la Constitución y de los derechos fundamentales que forman parte de ella. En particular, realiza una nueva interpretación del derecho al proceso debido (art. 24.2 CE), al amparo del estándar ofrecido por el Tribunal Europeo de Derechos Humanos, superior al contenido en la Decisión Marco 2002/584/JAI del Consejo. De esta forma el Tribunal Constitucional opta por no renunciar a su competencia y a su función de garante de los derechos fundamentales, estableciendo un nivel de protección superior al ofrecido por el Tribunal de Justicia de la Unión Europea.

Compartir plenamente esta construcción supone aceptar, también, que el principio de primacía del Derecho comunitario tiene un carácter limitado (idea que se deriva, sin más complejidades, del artículo 31 de la Ley 25/2014, de 27 de noviembre, de Tratados y otros Acuerdos Internacionales). Esta construcción hace que nos separemos de los Votos Particulares suscritos por las Magistradas Asua Batarrita (que defiende una visión absoluta del principio de primacía) y Roca Trías (que entiende que el Tribunal Constitucional debería haberse limitado, en este caso, a ejecutar — sic — la resolución dictada por el Tribunal de Luxemburgo).

En definitiva, nos parece ejemplar la STC 26/2014, ya que acierta en el fondo del asunto planteado (la desestimación del amparo solicitado) y reivindica el lugar que el Tribunal Constitucional debe ocupar en cualquier ordenamiento constitucional moderno que merezca tal nombre. Y alumbra una idea más que es preciso subrayar: el hecho de que el Tribunal de Justicia determine que una norma comunitaria no lesiona los derechos fundamentales de la Unión, o recuerde que debe ser respetada por los operadores jurídicos nacionales, no excluye (no puede excluir, por principio) una eventual lesión de derechos constitucionales. Ello es así porque en muchas ocasiones la vulneración del derecho fundamental tiene su origen en una indebida o defectuosa aplicación de un precepto normativo y no en la ilicitud de éste. Por esta razón, serán los tribunales nacionales (y el Tribunal Constitucional, en último lugar), el encargado de determinar si la lesión aducida en la demanda de amparo ha concurrido o no.

No tenemos la misma opinión ni de la Sentencia del Tribunal de Justicia de la Unión Europea recaída en el asunto Melloni (de 26 de febrero de 2013) ni de Conclusiones presentadas por el Abogado General Yves Bot (de 2 de octubre de 2012). En estas últimas se realizan algunas afirmaciones gruesas, que precisarían de muchas matizaciones para poder ser ponderadas. Las dos más polémicas, se refieren a la identidad nacional (art. 4.2 TUE) y a la naturaleza del artículo 53 de la Carta de los derechos fundamentales de la Unión Europea. En relación con la primera se dirá que el régimen de dos derechos fundamentales (al proceso debido y de defensa) es ajeno a la identidad nacional (apartado 140). Y el Abogado General Ives Bot indicará que no debe subestimarse «el valor político y simbólico» del artículo 53 CDFUE (apartado 129), antes de vaciarlo de contenido jurídico (de contenido jurídico propio, se quiere indicar) (especialmente en los apartados 134 y 135 de sus Conclusiones). 
La Sentencia del Tribunal de Justicia de la Unión Europea se mueve en los mismos parámetros, si bien de forma algo más amable. Elude toda referencia a la identidad nacional en su resolución, lo que resulta sorprendente en un asunto como éste. Obvia, igualmente, el considerando duodécimo de la Decisión Marco cuestionada, en la que se afirma taxativamente que esta norma «no impedirá a ningún Estado miembro aplicar sus normas constitucionales relativas al respeto del derecho a un proceso equitativo». Y viene a afirmar que el margen de actuación nacional en la protección de los derechos fundamentales es nulo cuando existe un consenso europeo, como es el que se expresa sobre la orden europea de detención y entrega en la Decisión Marco.

Este Sentencia resulta cuestionable por diversas razones.

En primer lugar, porque sitúa a los derechos fundamentales por debajo del principio de primacía del Derecho de la Unión y de los principios de confianza y de reconocimiento mutuo de la orden europea de detención y entrega, obviando, además, sus propios presupuestos.

También resulta cuestionable, en segundo lugar, que en el estudio de la compatibilidad entre la Decisión Marco y la Carta el Tribunal de Justicia no analice la posición del Tribunal Europeo de Derechos Humanos en la materia, ya sea para respaldarla o matizarla. Esta omisión es cuestionable porque, como es sabido, todas las autoridades nacionales europeas están obligadas a respetar el Convenio Europeo de Derechos Humanos.

Pero es que además, esta Sentencia posee, por definición, un alcance mucho más limitado del pretendido. Si se piensa bien, lo único que en ella se indica es que la Decisión Marco es compatible con la Carta y que las autoridades nacionales están obligadas a proceder a la detención y entrega del afectado cuando se cumplan las condiciones en ella previstas. Ahora bien, como ya se ha avanzado, resulta ingenuo pensar que la validez de una norma evita cualquier lesión de un derecho fundamental cuando ésta se aplica. La experiencia demuestra, al contrario, que la lesión de los derechos fundamentales tiene su origen en el mayor número de los casos por la indebida aplicación de un precepto legal válido. Quiere esto decir que, en tales hipótesis, el control ejercido por los tribunales estatales (por el Tribunal Constitucional, en último extremo) seguirá siendo ineludible.

\section{JUAN LUIS REQUEJO PAGÉS}

La respuesta del Tribunal de Justicia era la que cabía esperar de un Tribunal cuyo activismo en el proceso de integración ha sido fundamental para que el Mercado Común se haya convertido en la Unión que hoy conocemos. Con muchos menos mimbres que los que le ofrece el Tratado de Lisboa, el Tribunal de Justicia ha sido capaz de construir los principios de primacía y de eficacia directa. Disponiendo ahora de la Carta — con toda la potencialidad expansiva que, en términos competenciales, es inherente a una declaración de derechos-, el Tribunal de 
Justicia no podía sino interpretar de manera restrictiva las disposiciones de la Carta que condicionan y limitan su propia interpretación y aplicación.

El Tribunal de Justicia ha aprovechado la pregunta del Tribunal Constitucional para, de consuno con su respuesta a la cuestión prejudicial planteada por un Tribunal penal sueco en el asunto Akerberg Fransson (resuelto también por la Gran Sala en la misma fecha que el asunto Melloni), sentar las bases del régimen de articulación del Derecho de la Unión y de los Derechos nacionales en el ámbito de los derechos. Como pieza fundamental de ese régimen se ha establecido el principio de que, allí donde la aplicación de la Carta no deja margen alguno de apreciación a los Estados miembros, es irrelevante que éstos dispensen una mayor protección constitucional al derecho concernido.

Es difícil exagerar la importancia de esta declaración de principio, pues, con independencia de su mayor o menor corrección desde el punto de vista de los Tratados, supone una seria contestación a los regímenes nacionales de garantía de los derechos y, muy en particular, a la función tutelar de los Tribunales Constitucionales. En realidad, la doctrina Melloni/Akerberg Fransson sólo puede interpretarse como un nuevo episodio en la larga lucha por la soberanía que la Unión viene librando con los Estados miembros desde los primeros años del proceso de integración y que tiene sus protagonistas principales en el Tribunal de Justicia y en el Tribunal Constitucional alemán.

Al plantear ante el Tribunal de Justicia el asunto Melloni, el Tribunal Constitucional se había dado la oportunidad de asumir algún protagonismo en esa contienda, defendiendo la posición común de las jurisdicciones constitucionales frente a la causa del Tribunal de Justicia. Sin embargo, al reaccionar como lo ha hecho en la STC 26/1994, el Tribunal Constitucional ha dejado claro que no está a la altura de esa empresa.

La STC 26/2014 ha sido, ante todo, una ocasión perdida. Pero ha sido también, sobre todo, un ejemplo de grave desorientación por parte del Tribunal Constitucional en lo que hace a su lugar en el entramado institucional de la Unión. De entrada, el Tribunal Constitucional no parece ser consciente de lo que supone plantear una cuestión prejudicial ni del significado y alcance de la respuesta del Tribunal de Justicia. A su juicio, el hecho de haberla planteado es algo que, simplemente, «[c]onviene comenzar poniendo de manifiesto» (STC 26/2014, FJ 2), en tanto que, para el Pleno, la respuesta del Tribunal de Justicia «nos será de gran utilidad» (loc. cit., in fine). A partir de ahí, el asunto se resuelve con la cita de varias resoluciones del Tribunal Europeo de Derechos Humanos y del propio Tribunal de Justicia, refiriéndose entre estas últimas, como una más, a la sentencia Melloni (STC 26/2014, FJ 4, párrafo 11, in fine). En definitiva, el recurso de amparo cuya tramitación hubo de suspenderse para plantear la cuestión prejudicial se resuelve en los mismos términos en los que podría haberse resuelto sin necesidad de haber acudido al Tribunal de Justicia.

De manera ostentosa, el Tribunal Constitucional ha querido hacer abstracción de la sentencia Melloni en lo que verdaderamente vale; esto es, como interpretación 
del Derecho de la Unión de la que ningún Tribunal nacional puede desvincularse, menos que nadie quien la ha solicitado. El Pleno ha alcanzado, desde luego, el resultado que necesariamente se imponía tras la sentencia de Luxemburgo, pero no ha querido hacerlo como consecuencia de un mandato del Tribunal de Justicia, sino motu proprio. Incluso puede advertirse una negativa velada a asumir la doctrina Melloni/Åkerberg Fransson. De otro modo no se entiende el sentido del fundamento jurídico 3 de la STC 26/2014, que, con su recordatorio de los límites y condiciones establecidos en la DTC 1/2004 al proceso de integración, adquiere el tono de una suerte de amenaza. Un recordatorio con el que, en palabras del Pleno, se quiere «completar la respuesta del Tribunal de Justicia» (STC 26/2014, FJ 3, ab initio) y que con toda justicia ha suscitado la crítica del voto particular suscrito por la Magistrada Sra. Asua Batarrita, quien, en la línea del voto particular firmado por la Magistrada Sra. Roca Trías, también lamenta la ocasión perdida de contribuir a la construcción del modelo europeo de articulación de jurisdicciones en el ámbito de los derechos fundamentales.

Frente a esta reacción disimulada y pusilámine, el Tribunal Constitucional alemán ha hecho valer de nuevo su condición de adalid de la causa de las Constituciones nacionales. Su sentencia de 15 de diciembre de 2015 (2 BvR 2735/14) es inequívoca en cuanto a la prevalencia última de la Ley Fundamental de Bonn en materia de derechos fundamentales, más allá de lo que resulte de los Tratados y de la jurisprudencia del Tribunal de Justicia, al que el Tribunal alemán no duda en corregir, desautorizando la doctrina Melloni. Me referiré a esta cuestión al responder a la siguiente pregunta. Ahora me interesa sólo señalar, por un lado, que la doctrina Melloni/Åkerberg Fransson demuestra hasta qué punto una declaración de derechos puede servir a una jurisdicción proactiva para expandir los límites competenciales de la Unión. Por otro, que, frente a la vocación expansiva del Derecho de la Unión, las jurisdicciones constitucionales pueden oponer una resistencia basada en la ignorancia o en la contestación. El Tribunal Constitucional español parece haberse inclinado por la primera variante; el alemán, por la segunda. El Tribunal de Justicia, entre tanto, tiene a su favor la lógica de la integración, pero ha de contar con un obstáculo de principio: la naturaleza misma de la Unión en tanto que comunidad de Estados. A ello me refiero también en la respuesta siguiente.

3. A la vista de esta primera experiencia, ¿considera que «está en la lógica de las cosas» que los Tribunales Constitucionales se conviertan, merced al planteamiento de estas cuestiones prejudiciales, en «clientes habituales» del TJUE?

\section{FRANCISCO BALAGUER CALLEJÓN}

En mi opinión, está en la lógica de las cosas que haya una mayor colaboración entre los tribunales constitucionales nacionales y el TJUE. Esa colaboración 
resulta esencial si tenemos en cuenta que los ordenamientos europeo y nacional deben integrarse armónicamente en beneficio de los derechos de la ciudadanía europea. Por tanto, es necesario que el TJUE tenga cada vez más en cuenta el Derecho constitucional nacional, como de hecho está haciendo en algunas decisiones y, al mismo tiempo, que los tribunales constitucionales nacionales sean conscientes de que tienen que utilizar el Derecho de la Unión en su labor de enjuiciamiento e integrarlo cuando sea necesario en el parámetro de valoración de la constitucionalidad. En un contexto de integración supranacional, la constitucionalidad es una realidad compleja que no puede limitarse exclusivamente a los preceptos constitucionales sino que tiene que tener en cuenta también la incidencia de las normas supranacionales cuando sea procedente.

\section{RAFAEL BUSTOS GISBERT}

Ya he contestado parcialmente a esta pregunta al responder a la primera cuestión planteada. Creo que era una anomalía que los Tribunales Constitucionales nacionales no plantearan cuestiones prejudiciales. También he apuntado cuáles, a mi juicio, eran los motivos. Sin embargo, para que el sistema funcione era inevitable que finalmente los Tribunales Constitucionales plantearan cuestiones prejudiciales. Nótese que tras el planteamiento de la cuestión por España, otros Tribunales constitucionales se han animado. Así antes de la cuestión planteada por el TC español las habían suscitado con frecuencia la Corte Constitucional belga, en alguna ocasión el Tribunal Constitucional austríaco y en un solo caso la Corte Costituzionale italiana y la Corte Constitucional lituana. Tras el TC español han planteado cuestiones, además, Luxemburgo, Alemania, Polonia, Francia o Eslovenia. Pero ya estaba en la jurisprudencia alemana claro que el planteamiento de cuestión prejudicial sería inevitable cuando la doctrina Solange no fuera suficiente para solucionar los eventuales conflictos entre Derecho de la UE y algún aspecto de la Constitución nacional (véase el trabajo de Maribel González Pascual, El Tribunal Constitucional Alemán en la construcción del espacio europeo de los Derechos, 2010).

Pero no creo que sea casual que varios Tribunales Constitucionales hayan asumido al mismo tiempo que, efectivamente, se encontraba en la lógica de las cosas el planteamiento de cuestiones prejudiciales. Al contrario, parece que la entrada en vigor de la CDFUE ha despertado simultáneamente al TJUE y a los Tribunales Constitucionales del letargo en el que estaban sumidos gracias a la doctrina Solange. El TJUE ha venido desarrollando de manera lenta pero constante un discurso de los derechos fundamentales cada vez más elaborado, en parte como consecuencia de la proliferación de cuestiones prejudiciales nacionales en las que se alegan posibles violaciones a la CDFUE tanto por la normativa de la UE como por la normativa nacional en su aplicación. Para los jueces ordinarios europeos parece que la codificación de los derechos de la UE en la Carta ha sido 
una suerte de pistoletazo de salida para plantear cuestiones prejudiciales fundadas, aunque sea parcialmente, en derechos fundamentales. Ello, obviamente, ha provocado la necesidad de pronunciarse sobre esos temas en el TJUE. De este modo en los Tribunales Constitucionales ha aumentado la conciencia de que la defensa de los derechos de los ciudadanos no se articula ya solo a través de su intervención resolviendo los casos nacionales, sino mediante su participación en el proceso europeo de defensa de los derechos. La participación de los Tribunales Constitucionales ha pasado de ser oculta a expresa.

La participación oculta era la elegida hasta ahora. Consistía en la formulación de los grandes principios de relación entre ordenamientos y de los límites a la integración. A ello se unía la renuncia al ejercicio de una jurisdicción de control del Derecho de la UE en tanto este respetara los derechos fundamentales de modo equivalente a como se garantizaban en el orden nacional (doctrina Solange). Pero advirtiendo que una violación flagrante de los derechos podría suponer que ejercieran un auténtico control interno de constitucionalidad sobre el derecho de la UE. De este modo los Tribunales Constitucionales marcaban grandes pautas o límites normalmente con motivo del ejercicio de sus competencias sobre la constitucionalidad de los tratados constitutivos. Ejercido este control general se limitaban a alertar, en sentencias muy significadas e infrecuentes, frente a peligros concretos planteados en supuestos individualizados. Últimamente, la participación se ha convertido en expresa mediante el uso de la cuestión prejudicial. Esta es la participación que ha cambiado. Los Tribunales Constitucionales han comenzado a participar activamente porque posiblemente se han dado cuenta de que ese es el espacio natural que les confiere el derecho de la Unión y, por otra parte, en ese espacio pueden garantizar no solo los derechos de sus ciudadanos sino contribuir a garantizar los de todos los ciudadanos de la UE. Si se quiere en otros términos, los Tribunales Constitucionales han descubierto que son, igual que el resto de jueces nacionales, por definición también Tribunales de la Unión. Y de alguna manera, como se trata de explicar a continuación, Tribunales Constitucionales de la UE.

En cuanto tribunales de la Unión y dadas sus competencias internas, estos tribunales son los más adecuados para contribuir de manera esencial al cumplimiento de una de sus tareas esenciales como es la defensa de los derechos. Nunca debe olvidarse que la estructura del poder judicial de la UE es muy particular. No debe olvidarse que el acceso al TJUE concedido a los ciudadanos es muy limitado. No debe olvidarse que una decisión del juez nacional en aplicación del Derecho de la UE no es recurrible por el particular ante el TJUE (en ausencia de nada parecido a la casación o al amparo). Por ello, debe ser el juez nacional y muy singularmente la jurisdicción constitucional de la libertad (como la definió Cappelleti en Italia o Cascajo en España) la que asuma un papel básico en la defensa de los derechos. Solo si los jueces nacionales plantean cuestiones prejudiciales suscitando problemas de compatibilidad entre el Derecho de la UE o el derecho nacional en aplicación de aquél y los derechos fundamentales contenidos en la Carta se podrá garantizar plenamente el respeto a los derechos en la UE. Y 
en esta tarea los Tribunales Constitucionales deben abandonar su papel oculto y convertirse en la instancia que plantee aquellas cuestiones que los tribunales ordinarios no han planteado. Por tanto, la respuesta a la pregunta final es clara. No se puede afirmar tajantemente si efectivamente los Tribunales Constitucionales acabarán siendo los clientes habituales, pero sí desde luego deberían serlo.

Por otra parte, y ya en un terreno más concreto, los Tribunales Constitucionales con la entrada en vigor de la CDFUE (y la sentencia Melloni es un buen ejemplo) necesitarán de la intervención del TJUE a menudo para determinar dos aspectos que condicionan su propia labor de defensa interna de los derechos constitucionales. Por un lado, deberán cuestionar al TJUE cuando tengan dudas acerca si es o no de aplicación la CDFUE, pues establecer dicho ámbito de aplicación corresponde obviamente a Luxemburgo. Por el otro, si la CDFUE es de aplicación, deberán preguntar cuál es el margen de apreciación dejado por el Derecho de la UE para permitir, en su caso, la aplicación de estándares de protección superiores derivados de la Constitución nacional.

\section{ASCENSIÓN ELVIRA PERALES}

Es perfectamente lógico que los TTCC recurran al TJUE, puesto que necesariamente han de aplicar Derecho de la UE para la resolución de sus asuntos. En los primeros años de funcionamiento de las Comunidades Europeas, debido a las limitadas competencias atribuidas era fácil defender la separación entre el ordenamiento europeo y el interno, al menos en lo tocante a aspectos constitucionales, sin embargo la ampliación de competencias que se ha venido produciendo a partir del Tratado de Maastricht y el pleno reconocimiento de efectos jurídicos a la Carta de Derechos Fundamentales que efectúa el Tratado de Lisboa conducen a que cada vez resulte más difícil llevar a cabo una separación clara entre los dos ordenamientos, dada la 'contaminación' del Derecho europeo que impregna buena parte del ordenamiento interno.

En esa línea hay que tener presente que los tribunales constitucionales están obligados al cumplimiento del Derecho UE al igual que cualquier operador jurídico, obligación que conlleva el planteamiento de cuestiones prejudiciales para cualquier órgano jurisdiccional (incluidos los primeros) cuando se den las condiciones impuestas por el ordenamiento de la UE (art. 267 TFUE) y la propia doctrina del TJUE; en última instancia, recordemos, la no presentación de una cuestión prejudicial puede dar lugar a un recurso por incumplimiento del Estado, lo cual es mera retórica pues cabe recordar que el recurso por incumplimiento de España del asunto C-154/08 vino provocado por la falta de presentación de una cuestión prejudicial por parte del Tribunal Supremo y la interpretación que este ofreció de la normativa controvertida.

Más allá de eso, para todos los operadores jurídicos resulta conveniente un acercamiento de posturas y además la formulación de cuestiones prejudiciales permite al 
TJUE un mejor conocimiento de los ordenamientos internos y de la tradición constitucional correspondiente, en particular cuando el implicado es el TC, lo que permite, a su vez, que el TJUE pueda asimilarla en aquellos casos en los que recurre en su argumentación a 'las tradiciones constitucionales' de los estados miembros. El denominado 'diálogo' entre tribunales es fecundo para ambas partes.

En el caso del Tribunal constitucional español sería conveniente que acabara con esa especie de esquizofrenia que vive frente al Derecho Europeo: por un lado, en aquellos asuntos en los que está implicado el TJUE al obedecer el planteamiento del recurso de amparo a la invocación del art. 24 CE por falta de planteamiento de una cuestión prejudicial, supuestos en los que el TC parece buscar la defensa de sus competencias y la separación de las mismas del ámbito de la Unión para justificar que en su actuación solo ha de ceñirse a la Constitución: las SSTC 58/2004, 194/2006, 78/2010, 145/2012, 212/2014, 232/2015 son buena prueba de ello, si bien se aprecian vaivenes apreciables en ellas que han sido objeto de numerosos comentarios doctrinales. Un supuesto similar de querer forzar la separación se ha producido con ocasión del planteamiento de su primera cuestión prejudicial, de acuerdo con lo expuesto. De igual forma, seguramente en alguna ocasión anterior el Tribunal Constitucional hubiera debido plantear una cuestión prejudicial, como sucediera en los asuntos que dieron lugar a la SSTC 28/1991, 45/1996 o 199/2009.

Por el contrario, cuando simplemente se trata de supuestos en los que para la resolución del caso resulta aplicable la normativa europea (incluida la doctrina del TJUE), el TC no duda en aplicarlo en todo tipo de procesos al igual que haría cualquier órgano de la jurisdicción ordinaria (como por otra parte ha de hacer), lo mismo que cuando se sirve de la jurisprudencia del TJUE para motivar una sentencia o para apoyar su interpretación. Esta asunción del Derecho de Unión Europea se aprecia desde la resolución de recursos de amparo (162/2016, 66/2015, $232 / 2015 \ldots)$ a recursos $(157 / 2016,193 / 2013 \ldots$ ) o cuestiones de inconstitucionalidad (121/2016, 71/2016, 58/2016 en una autocuestión...). En este sentido, la jurisprudencia sobre el principio de no discriminación por razón de sexo ha tenido un gran apoyo en la legislación y doctrina del TJUE: discriminación directa (SSTC 136/96, 42/2002 ...), acceso al trabajo (SSTC 229/1992), discriminación indirecta 145/1991, 240/1999, 61/2013, 110/2015 ..), o discriminación inversa (12/2008, 13/2009); protección de datos (292/2000, 17/2013...); normas penales en blanco $(7 / 1994,120 / 1998)$ e incluso para resolver un asunto vinculado al ius in officium de los parlamentarios (177/2002), por reflejar solo algunos de los supuestos más destacados, pero donde cabrían muchos más ejemplos. Incluso cabe recordar que el TC se refirió a la CDFUE antes siquiera de su solemne proclamación con ocasión de la cumbre de Niza en diciembre de 2000 (STC 292/2000, de 30 de noviembre). Sin embargo, siempre cabe recurrir a las palabras del juez Scalia y considerar que se cita el Derecho extranjero cuando se está de acuerdo con él y no en caso contrario... (A conversation between U.S. Supreme Court justices (2005) 3 International Journal of Constitutional Law 519) pero la 
reiterada invocación del Derecho europeo difícilmente puede encasillarse en un mero oportunismo.

Por tanto, la crítica que en ocasiones se ha hecho al Tribunal Constitucional de olvidar el Derecho de la Unión Europea y su significado no consideramos que sea cierta con carácter general, aunque si pueda serlo en supuestos concretos. La apariencia es que cuando el TC no teme por sus competencias actúa con plena asunción del derecho de la Unión, mientras cuando entra en juego una supuesta rivalidad con el TJUE, el TC busca una separación de ordenamientos inexistente en la realidad.

\section{JOSÉ MARTÍN Y PÉREZ DE NANCLARES}

Sí en usuario de un instrumento de cooperación judicial como la cuestión prejudicial. No creo, sin embargo, que ese usuario lo sea de manera habitual. No será habitual, porque ciertamente el número absoluto de cuestiones prejudiciales que pueda plantear nuestro Tribunal Constitucional nunca será por definición equiparable al que emane de los jueces y tribunales ordinarios, incluido el Tribunal Supremo, que son los órganos jurisdiccionales naturales para solicitar parecer (interpretativo o de validez) del TJUE. Recuérdese, a este respecto, que entre 1986 y finales de 2014 los órganos jurisdiccionales españoles plantearon 354 cuestiones prejudiciales, de las que solo una correspondió al Tribunal Constitucional, 53 al Tribunal Supremo y 300 al resto de órganos jurisdiccionales españoles (datos extraídos de R. SILVA DE LA PUERTA, «El Tribunal de Justicia de la Unión Europea», en E. NASARRE GOICOECHEA y F. ALDECOA LUZARRAGA (coords.), Treinta años de España en la Unión Europea - El camino de un proyecto bistórico, Marcial Pons, Madrid, 2015, pp. 145-150, en p. 149).

Con todo, el Tribunal Constitucional sí podría (y debería) ser usuario natural. Dicho de otra manera. El planteamiento de una cuestión prejudicial por el Tribunal Constitucional no debería verse como algo extraordinario. A nuestro juicio, el ámbito de los derechos fundamentales podría ser un caldo de cultivo adecuado para una interacción entre ambos tribunales a través del reenvío prejudicial, especialmente cuando los Estados apliquen Derecho de la Unión y pueda surgir alguna duda sobre el estándar de protección de un mismo derecho protegido tanto por la Carta de Derechos de la Unión Europea como por la Constitución nacional. No puede excluirse tampoco que pueda surgir la posibilidad en otros ámbitos de competencia de la Unión con potencialidad de conflicto, v.gr. la Unión Monetaria o el Espacio de Libertad, Seguridad de Justicia. En realidad, la doctrina Honeywell del Tribunal Constitucional alemán, a la que nos referiremos específicamente en la contestación a la siguiente pregunta, no es mal punto de partida para articular la espinosa cuestión de la posibilidad de fijar límites a la atribución de competencias a la Unión previstas en las respectivas cláusulas europeas de las Constituciones nacionales y, por ende, resolver la cuestión de si los Tribunales Constitucionales podrían realizar en casos extremos un 
control ultra vires de actos de la Unión. Ello presupone, por tanto, el previo planteamiento de la cuestión prejudicial al TJUE por parte de los Tribunales Constitucionales, como de hecho ha ocurrido también en Alemania en el reciente asunto Ganweiler.

\section{JAVIER MATÍA PORTILLA}

Ya hemos adelanto que, a nuestro juicio, el Tribunal Constitucional no aplica, en puridad, Derecho de la Unión, por lo que no debería, en principio, plantear cuestiones prejudiciales ante el Tribunal de Justicia de la Unión Europea.

Es probable que esta afirmación, que se hace desde una perspectiva dogmática, no sea compartida por los ilustres colegas que cumplimentan esta misma encuesta y exige, por ello mismo, una mayor justificación.

Desde una perspectiva general, el Tribunal Constitucional es el garante de la Constitución. Su papel nuclear, como es bien sabido, es controlar la constitucionalidad de las normas con fuerza de Ley tomando en consideración los preceptos constitucionales. En esta primera tarea solamente está vinculado, como no puede ser de otra forma, por la Constitución y la Ley Orgánica del Tribunal Constitucional.

El Tribunal Constitucional conoce también del recurso de amparo, pero lo hace, no debe olvidarse, en relación con determinados derechos constitucionales, que son los únicos que pueden invocarse ante él. Esto supone que si hay derechos humanos que no se encuentran recogidos entre los fundamentales no podrán ser tutelados a través del amparo constitucional (lo que ocurre, por ejemplo, con los derechos a la reagrupación familiar o al disfrute de su mutua compañía de padres e hijos, SSTC 236/2007 y 186/2013 —aunque, paradójicamente, haya forzado el derecho a la intimidad y a la inviolabilidad del domicilio para incluir el derecho al silencio en las SSTC 119/2001 y 16/2004-).

Esto nos permite entender que los derechos fundamentales de la Unión y los derechos humanos operan, en nuestro país, de desigual forma para el poder judicial y el Tribunal Constitucional. Para el primero son reglas jurídicas que deben ser aplicadas cuando corresponda. Para el Tribunal Constitucional son, como indica el artículo 10.2 CE, una fuente de interpretación que puede ser tomada en consideración para determinar el contenido y alcance constitucional de un derecho fundamental. Y el artículo 2 de la Ley Orgánica 1/2008, de 30 de julio, por la que se autoriza la ratificación por España del Tratado de Lisboa, confirma esta interpretación.

Si esta construcción no resulta desacertada, debe concluirse que el Tribunal Constitucional no debería, por principio, plantear cuestiones prejudiciales ante el Tribunal de Justicia de la Unión Europea porque no es, en puridad, juez comunitario. Este dato se ve también avalado por artículo 4 bis. 2 de la Ley Orgánica del Poder Judicial introducido por L.O. 7/2015, de 21 de julio.

Somos conscientes, sin embargo, de que la integración europea condiciona nuestras estructuras constitucionales profundamente (alterando el reparto de 
poder entre Gobierno y Parlamentos nacionales, alterando el papel de los entes territoriales políticamente descentralizados o ampliando las posibilidades de actuación del poder judicial). Y, desde esta realidad, podría darse alguna hipótesis singular en la que fuera posible aceptar que nuestro Tribunal Constitucional se valiera de la cuestión prejudicial. Lo que resulta más difícil de compartir es que Melloni fuera una de esas situaciones excepcionales, cuando, como ya se ha adelantado, el amparo solicitado ante el alto Tribunal estaba destinado al fracaso.

\section{JUAN LUIS REQUEJO PAGÉS}

Respondo de manera conjunta a las preguntas 3, 4 y 5 .

Son varias las perspectivas desde las que puede considerarse el planteamiento de una cuestión prejudicial, cada una con su propia lógica. Así, desde la perspectiva de la Constitución española «está en la lógica de las cosas» que el Tribunal Constitucional acuda al Tribunal de Justicia para recabar la interpretación auténtica de los derechos de la Carta cuando ello sea necesario para definir o perfilar el contenido de un derecho o libertad constitucionales. Como decía antes, el «autismo comunitario» no puede seguir siendo una opción para el Tribunal Constitucional. En virtud del artículo 10.2 CE, los derechos fundamentales reconocidos por la Constitución cuentan ahora con un nuevo parámetro para la definición de su propio contenido constitucional (la Carta) y con un nuevo intérprete autorizado (el Tribunal de Justicia), al mismo nivel que el Convenio de Roma y el Tribunal de Estrasburgo, respectivamente. La publicación oficial expresa de la Carta abunda en esta idea. Es llamativo que la Ley Orgánica 1/2008 no se haya limitado a autorizar en su artículo 1 la ratificación del Tratado de Lisboa, asumiendo la publicación oficial del Tratado por la Unión, sino que, además, haya reproducido íntegramente el texto de la Carta en su artículo 2. Quedan así descartados posibles reparos a la condición de la Carta como tratado comprendido en la referencia del artículo 10.2 CE a aquéllos «relativos a derechos fundamentales». Los Tratados constitutivos de la Unión no son, desde luego, tratados de esa especie y la integración de la Carta en el Derecho español por la intermediación del Tratado de Lisboa podría hacer dudosa su calificación como convenio del artículo 10.2 CE. Su publicación oficial separada como un convenio autónomo lo incluye en la definición constitucional de los tratados que disfrutan del valor interpretativo cualificado del artículo 10.2.

No sé si el Tribunal Constitucional será consecuente con lo anterior, pero sospecho que, aunque no lo fuera, no dejará por eso de plantear cuestiones prejudiciales. Le moverá a ello una «lógica» que no es la del artículo $10.2 \mathrm{CE}$, sino la del artículo 267 TFUE, es decir, la lógica del régimen mismo de la cuestión prejudicial. Para el Tribunal de Justicia, la cuestión del artículo 267 TFUE constituye un instrumento fundamental para garantizar la uniformidad, la primacía y la eficacia del Derecho de la Unión, objetivos en cuya persecución no duda en hacer sacrificio de los sistemas judiciales nacionales. «La más amplia facultad de 
someter al Tribunal de Justicia una cuestión de interpretación de las disposiciones pertinentes del Derecho de la Unión», por utilizar una expresión recurrente del Tribunal de Justicia, es, desde luego, inherente al mecanismo del artículo 267 TFUE, pero llevada al extremo termina conduciendo al apoderamiento de los órganos judiciales inferiores para hacer excusa de su sometimiento a la jerarquía de los Tribunales superiores, de manera que las jerarquías judiciales nacionales sencillamente desaparecen, sustituidas por un orden nuevo en el que, sobre la base del conjunto de los órganos judiciales de los Estados miembros, confundidos en una totalidad sin acepción de grado, se erige como única instancia jerárquicamente superior la del propio Tribunal de Justicia.

Esto es particularmente grave en el caso de la jurisdicción constitucional. El hecho de que los derechos fundamentales de la Constitución sean ahora también derechos fundamentales de la Carta supone que los Tribunales ordinarios pueden hacer valer la dimensión comunitaria de un derecho para inaplicar la ley nacional que consideren incompatible con el Derecho de la Unión o, en caso de duda, plantear una cuestión prejudicial al respecto. En los dos casos, obviando el trámite de la cuestión de inconstitucionalidad y aun la doctrina del Tribunal Constitucional en la materia de que se trate. Con la consecuencia, en definitiva, de reducir a la nada el privilegio jurisdiccional de la ley que está en la base de nuestro modelo de jurisdicción constitucional concentrada.

Si el Tribunal Constitucional no quiere verse reducido a la irrelevancia hará bien en anticiparse a los Tribunales ordinarios planteando al Tribunal de Justicia toda duda de interpretación de los derechos fundamentales a la luz de la Carta. No podrá impedir que los Tribunales ordinarios utilicen también la vía del artículo 267 TFUE, pero le será posible, al menos, obtener una respuesta del Tribunal de Justicia elaborada a partir de una pregunta propia, evitando los inconvenientes de una sentencia de Luxemburgo que le obligue a reconsiderar su propia doctrina a partir de una resolución en la que el Tribunal de Justicia sólo habrá podido desenvolverse en el contexto normativo, dogmático y circunstancial ofrecido por un Tribunal ordinario.

La «lógica de las cosas» es notablemente distinta en el caso del Tribunal Constitucional alemán. La suya sigue siendo la lucha por la defensa de la soberanía nacional frente a las pretensiones expansionistas de la Unión, cuya condición de criatura constituida por unos Tratados que tienen por señores a los Estados miembros no ha podido evitar su progresiva transformación en un temible protosoberano. Para el Tribunal alemán se ha tratado siempre, sobre todo, de trazar los límites en los que debe contenerse el Derecho de la Unión, vale decir: el Tribunal de Justicia. En el ejercicio de esa tarea el Tribunal Federal ha rendido el mejor servicio al Derecho de la Unión, cuya deriva por la senda del constitucionalismo, en general, y de la defensa de los derechos fundamentales, en particular, debe mucho a la vigilancia constante de Karlsruhe.

El Tribunal Constitucional alemán ha mantenido frente al Tribunal de Justicia una verdadera guerra de posiciones. Parapetado en un principio en la trinchera 
de los derechos fundamentales, ha tenido que ir retirando sus líneas a medida que el Derecho de la Unión ha ido asumiendo sus exigencias. De manera más que paradójica, ganada definitivamente la batalla de los derechos con la proclamación de la Carta de Niza y el sometimiento del Tribunal de Justicia al universo de los derechos fundamentales, el vencedor de esa batalla ha tenido que replegarse, fijando entonces su posición en la línea de la identidad constitucional y del respeto a la naturaleza atribuida y tasada de las competencias de la Unión. También en esa batalla ha salido triunfante el Tribunal alemán, una vez incorporado en los Tratados el principio del respeto de la identidad nacional y consagrado formalmente el principio de subsidiariedad. La paradoja es ahora, de nuevo, que esa victoria circunstancial puede llevar consigo la última derrota. Y ello porque, cediendo a las exigencias del Tribunal Constitucional Federal, el Derecho de la Unión ha ido privándole de sus razones para oponerse a la lógica sobre la que se articula la relación entre aquel Derecho y los ordenamientos nacionales, es decir, la lógica de la primacía, que no es, al cabo, otra cosa que la supremacía constitucional en sentido material. Pero, sobre todo, le ha privado del concepto «identidad nacional», que siendo ahora una categoría del Derecho de la Unión, es necesariamente un concepto autónomo, definido como tal por el propio Tribunal de Justicia, sin perjuicio del concurso que éste decida conceder a las instancias nacionales para la definición de un concepto que, en último término, sólo a él compete realizar.

En ese contexto, la cuestión prejudicial no ha sido para el Tribunal Constitucional alemán un instrumento de colaboración con el Tribunal de Justicia en aras de la garantía de la uniformidad del Derecho de la Unión. Tampoco, como en el caso español, un recurso necesario para el cumplimiento del mandato establecido en el artículo 10.2 CE. Ha sido más bien la vía que el Tribunal de Karlsruhe ha reservado al Tribunal de Justicia para que éste pueda justificarse frente a la imputación de que el Derecho de la Unión no ha respetado los límites en los que debe moverse por imperativo de la Ley Fundamental de Bonn.

La primera cuestión prejudicial planteada por el Tribunal Constitucional alemán con el asunto Ganweiler responde cabalmente a ese esquema. Para pronunciarse sobre un recurso de amparo en el que se denunciaba que la Unión había incurrido en ultra vires con el programa de Operaciones Monetarias de Compraventa adoptado por el Banco Central Europeo, el Tribunal Constitucional Federal ha querido contar con la versión del Tribunal de Justicia acerca del contenido y alcance de ese programa, de manera que, una vez ilustrado sobre el particular, pudiera decidir si cabía o no apreciar una actuación ultra vires. El Tribunal de Justicia al servicio, pues, del Tribunal Constitucional, en el entendido de que la última palabra sobre la licitud del programa en cuestión no correspondía al primero, sino al segundo.

Los términos en los que el Tribunal Constitucional alemán ha planteado la cuestión no han podido ser más arrogantes. Tampoco podía ser más condescendiente el tratamiento que le ha dispensado al Tribunal de Justicia en la sentencia con la que finalmente resolvió el recurso de amparo, por más que lo hiciera descartando la existencia de ultra vires (sentencia de 21 de junio de 2016, 2 BvR 2728/13 et a.). 
El entendimiento de la cuestión prejudicial como un incidente al servicio de la indemnidad de la Ley Fundamental alemana trae consigo una «lógica de las cosas» con la que el Tribunal Constitucional Federal es perfectamente consecuente al permitirse recabar para sí la competencia para corregir al propio Tribunal de Justicia en la interpretación de los Tratados. No sólo lo ha hecho al ofrecer en la sentencia de 21 de junio de 2016 la interpretación canónica que a su juicio merece la sentencia Gawweiler, sino al desautorizar la doctrina Melloni en la sentencia de 15 de diciembre de 2015, a la que antes me he referido. Con todo, la arrogancia de Karlsruhe y su abierta pulsión unilateralista no dejan de ser síntomas de su impotencia. El Tribunal alemán ha jugado tradicionalmente la carta de la amenaza, dejando pasar en no pocas ocasiones la oportunidad de hacerla efectiva. La sentencia de 21 de junio de 2016 ha sido la última, pero cabe recordar también la de 6 de julio de 2016 (Honeywell). Al plantear su primera cuestión prejudicial ha querido imbuir algún crédito a su política de vigilancia amenazante. Su problema es que, como antes decía, el Tribunal Federal termina siempre contando sus victorias por derrotas, pues en la medida en que el Derecho de la Unión ha ido interiorizando sus demandas, éstas se convierten en materia comunitaria y, por tanto, quedan bajo la jurisdicción del Tribunal de Justicia.

La Unión es demasiado importante para la República Federal de Alemania como para que el Tribunal Constitucional alemán llegue a darle el golpe de gracia que supondría la realización de sus repetidas amenazas. En esa certeza me parece que encuentra su mayor fuerza el Tribunal de Justicia. Está en «la lógica de las cosas», si nos referimos al proceso de integración como realidad histórica, que sea el Tribunal de Justicia — la Unión — quien finalmente se imponga en esta prolongada lucha por la soberanía. Sin embargo, y con toda la fortaleza que le concede esa posición de ventaja, el Tribunal de Justicia ha levantado la maquinaria formidable del Derecho de la Unión sobre una base extraordinariamente débil y precaria, pues una palabra de los Estados miembros bastaría para enviar a los Tratados a los archivos de la historia.

4. El Tribunal Constitucional Federal Alemán, tradicionalmente defensor de la soberania estatal y de la identidad constitucional de los Estados, ha matizado dicha posición al plantear cuestión prejudicial en el caso del Banco Central Europeo. ¿Querría hacernos algún comentario sobre este caso y, especialmente, sobre los efectos de la relación de cooperación de los Tribunales Constitucionales con el TJUE sobre el futuro de la identidad constitucional de los Estados?

\section{FRANCISCO BALAGUER CALLEJÓN}

Tanto los tribunales constitucionales como el Tribunal Europeo de Derechos Humanos deben participar en la labor conjunta de construcción de un 
espacio común de derechos a nivel europeo. Por lo que se refiere a los tribunales constitucionales nacionales, es preciso señalar que la identidad constitucional de los Estados no presenta solamente una vertiente conflictual, como es la que se deriva de su consideración como «contralímite», sino que puede operar también en relaciones de confluencia, como muestra su utilización por parte del Tribunal de Justicia en diversas sentencias en las que ha incorporado el Derecho constitucional interno como parte del parámetro de validez de las normas nacionales discordantes con el Derecho europeo, normas que han sido consideradas válidas teniendo en cuenta también esas particularidades del Derecho constitucional nacional. La identidad constitucional se utiliza aquí en un sentido amplio o extensivo para hacer referencias a particularidades de los sistemas constitucionales de los Estados que no necesariamente forman parte de la identidad nacional en sentido estricto, en cuanto núcleo duro o esencial del orden constitucional. En su sentido estricto, la identidad nacional es un concepto «de frontera» que presenta innegables problemas de concreción y dificultades, quizás insalvables, para hacerlo operativo como concepto jurídico que pueda ser objeto de aplicación jurisdiccional, de ahí que esta otra dimensión de la identidad nacional quizás permita dotarla de contenido, insertándola en una relación normalizada de confluencia entre ordenamientos jurídicos, que desactive su potencial político perturbador para el proceso de integración europea.

\section{RAFAEL BUSTOS GISBERT}

No soy un experto en la jurisprudencia del Tribunal Constitucional alemán que es, además, extraordinariamente compleja y matizada así que creo que no soy la persona indicada para contestar a la primera parte de la pregunta.

Respecto a la segunda parte de la pregunta, el concepto de identidad constitucional de los Estados resulta extraordinariamente complejo y está en construcción (véase en general, A. Saiz Arnaiz \& C. Alcoberro Llivina, National Constitutional Identity and European Integration, 2013) de modo que es difícil aventurar cómo acabará funcionando en el orden jurídico de la UE. Pero aún así, lo cierto es que no podrá construirse y dotar de contenido sin la intervención de los Tribunales Constitucionales.

Debemos asumir que la participación en la UE produce una transformación constitucional de primer orden. Y uso la palabra transformación entendida como una modificación general de las normas constitucionales nacionales como consecuencia de la pertenencia a la UE. Si se quiere, por usar un término más clásico, una mutación constitucional de naturaleza general u horizontal (esto es lo que la diferenciaría del concepto clásico de mutación). El concepto de identidad constitucional nos remite, en mi opinión, a la idea de límites a la profundidad y extensión de tal mutación aceptable no solo por los Estados, sino también por la propia 
UE pues no olvidemos que el art. 4.2 del TUE es una norma fundacional de la UE que sirve como límite para ella misma.

Pues bien, el Tribunal Constitucional nacional no puede ser ajeno a la determinación de qué aspectos constituyen la identidad constitucional de su Estado. $\mathrm{Al}$ contrario, es un actor esencial y básico.

En general en las relaciones entre Derecho de la Unión y Jurisdicción constitucional, ésta debe asumir una mutación en su posición institucional y, por ello, en sus funciones. Lo decíamos más arriba y hay que reiterarlo. Antes la Jurisdicción Constitucional era la instancia revisora última en materia de derechos constitucionales aplicados en el Estado. Ahora ya no lo es. Ahora lo es solo si la norma aplicada no entra dentro del ámbito de aplicación del Derecho de la UE. En estos casos, su posición muta desde ser la última instancia, a constituir un tribunal esencial en la garantía de los derechos derivados de la CDFUE y con ello en la construcción de un discurso común en materia de derechos fundamentales de la UE. De ser instancia última de decisión en todos los casos ha pasado a ser partícipe del proceso de decisión cuando estamos en el ámbito de aplicación de la CDFUE.

Con respecto a la identidad constitucional debe pasar algo parecido. Los Tribunales Constitucionales han pasado de ser los guardianes de la Constitución, frente a cualquier intento de modificación de la misma por vías diferentes a la reforma, a desempeñar un papel más modesto cuando nos encontramos en el campo de las competencias de la Unión. Este papel más modesto consiste en garantizar que la transformación/mutación constitucional derivada de la integración europea no supone la desaparición de los elementos básicos de la identidad constitucional nacional. $\mathrm{Y}$ en este papel garantista deberá tener en cuenta que en última instancia posiblemente la decisión no sea suya o, si lo es, lo sea a costa de hacer imposible la participación en la integración futura. Esto es, el papel básico de garantía será alertar al TJUE de que desde su perspectiva se está produciendo una violación del art. 4.2 TUE. Y su perspectiva no es la de un cualquiera. Es la del órgano nacional encargado de la supervivencia de la base constitucional última del Estado que forma parte de la Unión. De este modo, el TJUE, sometido a una petición de decisión sobre el alcance del artículo 4.2 TUE por un Tribunal Constitucional que considera dudoso el respeto a los elementos básicos de su propia Constitución, deberá ser extraordinariamente prudente. Deberá dar y esgrimir muy buenas razones. Razones que habrán de ser tanto más poderosas cuanto mejor haya sido el planteamiento de la cuestión por parte del Tribunal Constitucional nacional. Esto es, cuanto más en serio se tome el Tribunal Constitucional este nuevo papel de garante de la constitucionalidad nacional.

En definitiva, la cooperación y la deferencia deberán ser en este punto extraordinarias tanto para los órganos nacionales de defensa de la Constitución como para el TJUE, so pena de poner en riesgo la propia integración pues no debe olvidarse que tras la intervención del TJUE será el Tribunal Constitucional nacional 
el que acepte o no su decisión. En el caso de no aceptarla la crisis para la integración no habrá hecho más que empezar.

\section{ASCENSIÓN ELVIRA PERALES}

La historia del TJ de la Unión ha sido en alguna medida una historia de confrontación con el Tribunal Constitucional Federal Alemán (TCFA) y cabe recordar como la defensa de los derechos fundamentales en las Comunidades europeas por parte del TJ fue el intento de evitar que el TCFA sustrajese a su conocimiento aquellas cuestiones en las que se veían involucrados derechos. Las conocidas sentencia «Solange...» no son sino el capítulo inicial que ha continuado con otros casos (como el 'Bananas', por solo citar uno más) y que se ha reproducido cuando el TCFA se ha pronunciado sobre cada nueva reforma de los Tratados y su afectación constitucional. De alguna forma puede pensarse que la defensa de los derechos en la UE no hubiera avanzado igual sin el TCFA.

La cuestión prejudicial presentada el 14 de enero de 2014 (C-62/14) hay que conectarla con la previa Sentencia del TCFA de 18 de marzo de 2014 en la que se pronunciaba sobre varios recursos frente a la prevista compra de bonos soberanos en el mercado secundario, las denominadas operaciones monetarias de compraventa de títulos (OMT), por parte del BCE. La respuesta se reflejó en la Sentencia (Gran Sala) que el TJUE se pronunció el 16 de junio de 2015.

Tras la respuesta del TJUE a la cuestión prejudicial el TCFA, a su vez, se ha pronunciado en la Sentencia de 21 de junio de 2016 en la que reconoce la primacía del Derecho de la Unión siempre que este se mantenga dentro de los límites autorizados por los tratados y, a su vez, sean conformes con el principio de democracia y la defensa de los derechos reconocidos en la constitución alemana. El TCFA declara que no son contrarias a la Constitución las prácticas del BCE vinculadas a la OMT siempre que se mantengan dentro de la interpretación ofrecida por el TJUE, si bien insta al Gobierno Federal y al Bundestag a fiscalizar el programa OMT. En definitiva, la respuesta del TCFA ha seguido la línea habitual en los conflictos relacionados con la Unión Europea: respeto de los compromisos asumidos con la Unión siempre que se respete los límites fijados por los Tratados y, en consecuencia, la soberanía alemana.

En la respuesta anterior ya se ha contestado a la segunda parte de la cuestión, no obstante, sí querría señalar que el hecho de que si el TCFA, el tribunal constitucional en el que se miran el resto de tribunales constitucionales europeos, haya planteado una cuestión prejudicial, propiciará que las cuestiones prejudiciales se conviertan en un instrumento más en manos de las cortes constitucionales. A la vez pone de manifiesto que los tribunales constitucionales ya no pueden vivir de espaldas a la Unión Europea e invocar su tarea de intérpretes de la constitución para intentar sustraerse a las obligaciones que impone la pertenencia a la Unión. 


\section{JOSÉ MARTÍN Y PÉREZ DE NANCLARES}

En efecto, el asunto Gawweiler encarna el más reciente ejemplo (positivo) de cooperación entre el Tribunal Constitucional alemán y el TJUE. Por primera vez aquél, aplicando su doctrina Honeywell, plantea cuestión prejudicial ante el TJUE en una materia particularmente delicada y polémica en Alemania. Cierto que, dando siempre una de cal y otra de arena, el Alto Tribunal alemán, antes de aceptar a regañadientes la interpretación suministrada por el TJUE no se priva de dar una buena regañina al Tribunal de Luxemburgo. Sin duda, la cuestión de los límites a la atribución de competencias realizada por los Estados miembros a la Unión y, más concretamente, el concepto de 'identidad constitucional' constituye el tema a debatir los próximos años, tanto en la doctrina como en la jurisprudencia de los dos tribunales en liza. De cualquier forma, desde la perspectiva de la cooperación judicial (institucionalizada) entre los Tribunales Constitucionales y el TJUE, nos merece una valoración muy positiva que el Tribunal Constitucional alemán haya dado el paso de plantear una cuestión prejudicial al TJUE, pues en el fondo supone reconocer expresamente el papel de monopolio de interpretación del que goza el TJUE cuando esté en juego la interpretación del Derecho de la UE. Y valoración igualmente positiva merece que el Tribunal de Karlsruhe haya aceptado la interpretación suministrada desde Luxemburgo, máxime en una materia harto delicada para la opinión pública alemana. Después podrá hacerse toda una lista de críticas al pronunciamiento concreto del Tribunal Constitucional alemán, pero el mensaje que al Alto Tribunal alemán lanza al resto de Tribunales Constitucionales es claro (y positivo).

\section{JAVIER MATÍA PORTILLA}

Antes de dar respuesta a la presente pregunta merece la pena recordar que, mientras que en el ADN del Tribunal de Justicia de la Unión Europea está su misión de proteger la máxima vigencia del Derecho de la Unión Europea y el preferente lugar de los Tratados Comunitarios, cualquier Tribunal Constitucional que se precié garantizará la supralegalidad constitucional. No debe esperarse otra cosa ni del uno ni de los otros.

El Tribunal Constitucional Federal Alemán ha cuestionado la competencia del Banco Central Europeo para participar en un programa de adquisición de títulos de deuda pública emitidos por los Estados de la Eurozona (el conocido OMT, por su nombre inglés: Outright Monetary Transactions), dando lugar a la importante STJUE Gauweiler (C-62/14). De esta forma, el Tribunal Constitucional alemán ha seguido una senda ya transitada por otros órganos constitucionales, como el italiano (Autos 103/2008, de 15 de abril y 207/2013, de 18 de julio). ¿Permite este dato colegir que el Tribunal Constitucional Federal Alemán 
pone fin así a la defensa de la soberanía popular, del principio democrático y de los derechos fundamentales constitucionalmente garantizados?

Una primera respuesta, voluntarista, debería ser negativa, puesto que si un Tribunal Constitucional consagrara tal proceder, estaría olvidando que su función no es otra que garantizar la supremacía política y la supralegalidad normativa de la Constitución, cuya principal función es garantizar nuestra libertad. Y en esta línea de argumentación debemos recordar (brevemente, estas materias son bien conocidas) que las primeras reservas expresadas por los Tribunales Constitucionales a la primacía absoluta del Derecho Comunitario se realizan en relación con los derechos fundamentales (AATCFA Solange I -BVerfGE 37, 271-, de 29 de mayo de 1974 y Solange II —BVerfGE 73, 339-), los derechos inalienables de la persona y principios fundamentales del ordenamiento constitucional (SSTCI Frontini — 183/1973, de 18 de diciembre-y Granital - 170/1984, de 5 de junio-, entre otras), y el principio democrático (SSTCFA Maastricht BVerfGE 89, 155, de 12 de octubre de 1993- y Lisboa -BVerfGE 123, 267, de 30 de junio de 2009-).

Pero también los datos ocurridos con posterioridad al planteamiento de dicha cuestión avalan esta misma posición. Y lo hacen, bueno es llamar la atención sobre ello, sobre la orden europea de detención y entrega. No es sorprendente que sea sobre esta materia (regulada en la Decisión Marco 2002/584/JAI, modificada por la 2009/299/JAI), sensible a la protección de los derechos fundamentales y humanos, se hayan planteado distintas cuestiones prejudiciales por el Consejo Constitucional francés (Auto 2013-314P QPC, de 4 de abril) y los Tribunales Constitucionales belga (Sentencia 128/2009, de 24 de julio, entre otras muchas) y español (ATC 86/2011). Y hay quien sostiene que este listado debería haberse ampliado con una cuestión prejudicial planteada por el Tribunal Constitucional Federal alemán, que se debiera haber producido en un asunto relacionado con esa misma materia en 2015, bajo el imperio del Tratado de Lisboa.

Conviene recordar que, precisamente, este Tratado ahonda en la noción de identidad nacional, término que había aparecido en el artículo F.1 del Tratado de Maastricht. En efecto, la identidad nacional opera hoy como límite expreso a la actuación de la Unión a tenor de lo previsto en el artículo 4.2 TUE. Aunque estemos en presencia de un concepto jurídico indeterminado, resulta evidente que algún contenido debe poseer, siendo la única pista que nos brinda el citado precepto que resulta «inherente a las estructuras fundamentales políticas y constitucionales de éstos».

Pues bien, esta cláusula sería de utilidad si de ella se pudiera colegir, con naturalidad, una serie de materias concretas que conformaría la identidad nacional de los Estados miembros. Pero la experiencia reciente demuestra que las cosas no han cambiado, puesto que la interpretación de esta cláusula puede no ser pacífica.

Y esto es lo que ha situado nuevamente al Tribunal Constitucional Federal alemán en el centro de la polémica. Antes de explicar por qué, conviene recordar 
que en las Conclusiones del Abogado General Yves Bot presentadas en el caso Melloni éste expresa su convencimiento de que la determinación del alcance de dos derechos fundamentales «no puede afectar a la identidad nacional del Reino de España» (párrafo 140). Aunque el Tribunal de Justicia no confirma este parecer, tampoco lo cuestiona. Sí que lo hará, y frontalmente, el Tribunal Constitucional Federal Alemán en su Sentencia de 15 de diciembre de 2015.

En esta Sentencia (BvR 2735/14) se resuelve una demanda de amparo que atañe a una orden europea de detención y entrega. Lejos de plantear una cuestión prejudicial, el Tribunal Constitucional justifica su actuación en la causa en la identidad nacional (apartado 47), leído en relación con los artículos 23.1, 79.3 y 1 de la Constitución alemana. El Tribunal recuerda que resulta intangible el derecho a la dignidad (apartado 49). Entiende el Tribunal que a la vista de estas disposiciones una autoridad nacional puede no ejecutar una orden europea de detención y entrega si vulnera dicho derecho (apartado 83).

Se ha producido, pues, una nueva discrepancia entre el Tribunal de Justicia de la Unión Europea y el Tribunal Constitucional Federal alemán, en el que éste retoma la senda marcada por las resoluciones Solange I y Solange II. Es imposible saber si tal posición se justifica, total o parcialmente, en el excesivo rigorismo de la STJUE Melloni (resolución que llega a obviar el tenor empleado en el considerando duodécimo de la Decisión Marco, al que ya se ha hecho referencia). Pero lo cierto es que el Tribunal Constitucional Federal Alemán ha ejercido su competencia como garante del derecho a la dignidad en plenitud. La posición sostenida en la Sentencia (harto razonable, en todo caso) es que el las autoridades judiciales nacionales deben comprobar que han sido respetadas las exigencias derivadas del Estado de Derecho cuando aplican Derecho de la Unión.

Esta interesante Sentencia suscita algunas preguntas que deben ser respondidas. En primer lugar, ¿la reserva de jurisdicción se establece únicamente en relación con el derecho a la dignidad (art. 1 CA) o en relación con todos los derechos constitucionales? En segundo lugar, ¿quién debe ser el intérprete de la identidad nacional? Y en tercer lugar, ¿contribuye esta Sentencia a mejorar las cosas, o se puede presentar como un nuevo choque de trenes?

Pues bien, centrándonos ya en la primera cuestión planteada, Arzoz, en un magnífico análisis de la Sentencia, asume la limitada reserva contenida en el párrafo 49, entendiendo que solamente serán los vinculados con la dignidad (artículo $1 \mathrm{CA}$ ) (p. 127), y no todos los derechos fundamentales.

Sin embargo, resulta razonable defender que el control del Tribunal Constitucional debe alcanzar a todos los derechos fundamentales. Desde una perspectiva general, porque se ha indicado ya que el fin del Estado constitucional no es otro que asegurar la libertad de los justiciables a través del reconocimiento de determinados derechos fundamentales, que actúan como límite a la actuación de cualquier poder constituido. Y desde una perspectiva específica, relacionada con el concreto Estado español, porque éste ha establecido cuál es el (limitado) papel normativo de la Carta de los derechos fundamentales de la Unión Europea 
(artículos 10.2 CE y 2 de la Ley Orgánica 1/2008, de 30 de julio, ya citada) y la (también limitada) posición de los Tratados internacionales (artículo 31 de la Ley 25/2014, de 27 de noviembre, también citada). Esta construcción se compadece también con la afirmación realizada en la DTC 1/2004, de 13 de diciembre, cuando afirma que diversas disposiciones del fallido Tratado por el que se establece una Constitución para Europa (arts. I-6, I-5.1, I-2 y II-113) «vienen a consagrar la garantía de la existencia de los Estados y sus estructuras básicas, así como sus valores, principios y derechos fundamentales, que en ningún caso podrían llegar a hacerse irreconocibles tras el fenómeno de la cesión del ejercicio de competencias a la organización supraestatal» (FJ 3), ya que resulta plenamente aplicable a los Tratados en vigor.

La segunda cuestión alude a la competencia para interpretar la identidad nacional. Si entendemos, sin más, que estamos ante una disposición del Tratado, resulta evidente que la interpretación auténtica y uniforme de este precepto, como de cualquier otro, correspondería al Tribunal de Luxemburgo. Sin embargo, la realidad resulta, a todas luces, más compleja. De un lado, porque los ordenamientos constitucionales ponen límites al proceso europeo de integración (en nuestro caso marcados por la situación de los Tratados internacionales en el sistema de fuentes y por la posición subordinada de la Carta de Niza en relación con los derechos fundamentales; en otros casos por las cláusulas de intangibilidad recogidas en la Constitución). De otro porque resulta legítimo entender que existen peculiaridades que impiden (o dificultan) establecer un listado común de materias. Y la dignidad es un buen ejemplo de ello. Mientras que abre la Constitución alemana como el más relevante derecho fundamental, en nuestro ordenamiento constitucional no puede ser invocado directamente ante los Tribunales internos, pese a ser fundamento del orden político y de la paz social ex artículo 10.1 CE).

En todo caso, la identidad nacional es inherente a las estructuras fundamentales políticas y constitucionales de los Estados, «también en lo referente a la autonomía local y regional. Respetará las funciones esenciales del Estado, especialmente las que tienen por objeto garantizar su integridad territorial, mantener el orden público y salvaguardar la seguridad nacional. En particular, la seguridad nacional seguirá siendo responsabilidad exclusiva de cada Estado miembro». Parece claro, entonces, que la forma de Estado y de gobierno estaría amparada por la identidad nacional, como también aquéllas decisiones asociadas, de una u otra forma, a la soberanía (Requejo).

Si examinamos la jurisprudencia del Tribunal de Luxemburgo, tampoco avanzaremos gran cosa. Según este Tribunal, la identidad nacional no puede justificar la decisión del Gobierno de Luxemburgo de que los profesores de educación sean nacionales de su país y no de otros Estados de la Unión (STJUE Comisión c. Luxemburgo, de 2 de julio de 1996, asunto C-473-/93, considerando 35, en alusión al artículo F.1 TUE), pero sí que se decrete, mediante Ley, la abolición de la nobleza (STJUE — Sala Segunda — de 22 de diciembre de 
2010, C-208/09, considerando 83. En esta misma materia presenta evidente interés la STJUE — Sala Segunda— de 2 de junio de 2016, C-438/14, en la que se extiende dicha consideración al Estado alemán, pese a que queda claro que no forma parte de su identidad nacional, a diferencia de lo que ocurría en Austria - considerando 75-). También se vincula con la identidad nacional «la protección de la lengua oficial nacional del Estado» (STUE — Sala Segundade 12 de mayo de 2011, C-391/09, considerando 86. Ver, asimismo, STJUE - Gran Sala_ de 16 de abril de 2013, C-202/11, considerando 26) y el reparto de competencias entre la autoridad central del Estado y los entes territoriales políticamente descentralizados (SSTJUE — Sala Tercera- de 12 de junio de 2014, C-156/13, considerando 34 y - Sala Segunda - de 3 de septiembre de 2014, C-127/12, considerando 62, en relación con los Länder alemanes y las Comunidades Autónomas españolas).

Resultaría sorprendente que los Tribunales Constitucionales no fueran más lejos en la delimitación de la identidad estatal que se deriva de su ordenamiento constitucional. Por poner ejemplos concretos, resulta evidente que concretas exigencias derivadas del Estado de Derecho o del Estado democrático pudieran ser consideradas ajenas a nuestra identidad constitucional. Y lo mismo puede afirmarse, como ya se ha avanzado, de nuestros derechos fundamentales. Ello hace inevitable que en ocasiones los Tribunales Constitucionales se sientan obligados a hacer prevalecer un derecho constitucional sobre una concreta aplicación del Derecho de la Unión.

Resulta obvio que el ejercicio de esa reserva de jurisdicción debe manejarse con elemental prudencia y sentido común, y que solamente será ejercida de forma excepcional, como hace notar el Tribunal Constitucional Federal alemán en el considerando 46 de la Sentencia que comentamos. Y que, en tales casos, posibilite la actuación previa del Tribunal de Luxemburgo mediante la interposición de una cuestión prejudicial. Ahora se entenderá mejor que dejáramos abierta esta puerta en el último párrafo de la pregunta anterior.

No obstante, no debemos engañarnos. El control final lo tendrá el Tribunal Constitucional, quién puede decidir, como hace en este mismo caso, que no resulta preciso servirse de tal vía procesal por encontrarse en presencia de un acto claro y que no existen contradicción entre el Derecho de la Unión y el ordenamiento jurídico alemán, puesto que ambos protegen la dignidad de la persona (considerando 125). ¿Es tan grave este margen de actuación? ¿Es de veras tan grave que se rompa la uniformidad en la aplicación del Derecho de la Unión en contados casos, cuando se vean comprometidos derechos constitucionales? A nuestro modesto entender, es obvio que no. Por esta razón, defendemos que los Tribunales Constitucionales no deben abdicar en su función de proteger los derechos fundamentales cuando su ordenamiento jurídico habilita vías para su defensa.

Si se comparten estas tesis, debe ser uno pesimista en lo que atañe a la última subpregunta de esta cuestión, referida a la eventual colaboración (sic) de los 
Tribunales Constitucionales con el Tribunal de Justicia de la Unión Europea sobre el futuro de la identidad constitucional de los Estados.

No creemos, y es bueno decirlo ya de entrada, ni en la colaboración ni en el diálogo entre Tribunales. Si se piensa bien, mientras que el Tribunal de Justicia de la Unión Europea debe ser el máximo garante de los Tratados y tratará de maximizar su eficacia, los Tribunales Constitucionales existen para garantizar la supralegalidad constitucional. Y uno y otros deben esforzarse en cumplir con su función.

Esto supone que el problema de la primacía y los límites no tendrá fin. El Tribunal de Justicia siempre defenderá que el principio de primacía del Derecho comunitario sobre los ordenamientos nacionales es absoluto y alcanza a las disposiciones constitucionales (Sentencia Melloni, apartado 59). Y los Tribunales Constitucionales recordarán que no hay autoridad superior a la del poder constituyente, expresada en la Constitución, y establecerán sus reservas de jurisdicción (como recuerda el Tribunal Constitucional Federal alemán en el considerando 47 de la resolución citada en relación con las jurisdicciones de diversos Estados de la Unión (-Dinamarca, Estonia, Francia, Italia, Letonia, Polonia, España, Chequia y Reino Unido_- como recuerda Arzoz).

Por esta razón debemos apelar a la prudencia de todos los Tribunales en el respectivo ejercicio de sus competencias. Resulta evidente, por ejemplo, que cuando la norma de la Unión que regula la orden europea de detención y entrega ha generado una batería de cuestiones prejudiciales de tribunales constitucionales, el Tribunal de Luxemburgo debería haber mostrado una sensibilidad mayor a la demostrada en el Sentencia Melloni. Un posible cambio de rumbo, sugiere Arzoz, puede mostrar la Sentencia SSTJUE (Gran Sala) de 5 de abril de 2016 (asuntos C-404/15 y C-659/15 PPU), considerandos 82-104 y fallo, que relativiza el automatismo de la orden europea de detención y entrega por parte del juez que debe acordar la eventual entrega del interesado.

Y parece que el Tribunal de Justicia ha comenzado a descartar algunas prácticas discutibles relacionadas con la euroorden. Merece recordarse, en primer lugar, la STJUE (Sala Cuarta) de 24 de mayo de 2016 (asunto C-108/16 PPU), en la que se afirma que algunas expresiones contenidas en el artículo 4. bis de la Decisión Marco («citado en persona» y «recibió efectivamente por otros medios, de tal forma que pueda establecerse sin lugar a dudas que tenía conocimiento de la celebración prevista del juicio, información oficial de la fecha y lugar previstos») «son conceptos autónomos del Derecho de la Unión y deben interpretarse de manera uniforme en toda la Unión Europea». Pero lo hace entendiendo que no encaja en tal concepto de citación, la entregada en el domicilio de interesado a un adulto, sin que conste si, y en ese caso cuando, se entregó. Y en esta misma línea se inscriben las posteriores SSTJUE (Sala Cuarta) de 10 de noviembre de 2016 (asunto (C-452/16 PPU y C-477/16 PPU, respectivamente), en las que se indica lo mismo sobre el concepto «autoridad judicial 
emisora» (artículo 6.1 de la Decisión Marco), entendiendo que no lo son la Dirección General de la Policía Nacional sueca ni el Ministerio de Justicia de la República de Lituania.

Sin embargo, es probable también que esta jurisprudencia, más respetuosa con los derechos fundamentales, no sea siempre asumida por los Tribunales constitucionales estatales. Por ejemplo, resulta más discutible que el Tribunal de Justicia haya entendido que constituye una «resolución judicial» (artículo 8.1.c de la Decisión marco) una ratificación por el Ministerio Fiscal de una orden de detención nacional por un servicio de policía (STJUE — Sala Cuarta- de 10 de noviembre de 2016, recaída en el asunto C-453-16 PPU). El Tribunal entiende que «el concepto de resolución judicial se refiere a las resoluciones de las autoridades que participan en la administración de la justicia penal de los Estados miembros, con exclusión de los servicios de policía» (considerando 33). Es probable que este supuesto no plantee problemas en nuestro ordenamiento, donde es un órgano judicial quien acuerda la orden de detención, pero puede suscitarlo en otros de nuestro entorno.

En tales casos se producirán momentos tensos, como otros ya vividos con anterioridad (recuérdese la polémica derivada de la organización común del mercado de los plátanos), pero si provocan un reforzamiento de los derechos fundamentales de la Unión Europea, no serán en vano.

\section{JUAN LUIS REQUEJO PAGÉS}

Contestado en las respuestas dadas a la pregunta 3.

5. A la vista de lo anterior, ¿en qué posición quedan a su entender los Tribunales Constitucionales de los Estados miembros? ¿Y el Tribunal Europeo de Derechos Humanos?

\section{FRANCISCO BALAGUER CALLEJÓN}

Tanto los tribunales constitucionales como el Tribunal Europeo de Derechos Humanos deben participar en la labor conjunta de construcción de un espacio común de derechos a nivel europeo. Por lo que se refiere a los tribunales constitucionales nacionales, es preciso señalar que la identidad constitucional de los Estados no presenta solamente una vertiente conflictual, como es la que se deriva de su consideración como «contralímite», sino que puede operar también en relaciones de confluencia, como muestra su utilización por parte del Tribunal de Justicia en diversas sentencias en las que ha incorporado el Derecho constitucional interno como parte del parámetro de validez de las normas nacionales discordantes con el 
Derecho europeo, normas que han sido consideradas válidas teniendo en cuenta también esas particularidades del Derecho constitucional nacional. La identidad constitucional se utiliza aquí en un sentido amplio o extensivo para hacer referencias a particularidades de los sistemas constitucionales de los Estados que no necesariamente forman parte de la identidad nacional en sentido estricto, en cuanto núcleo duro o esencial del orden constitucional. En su sentido estricto, la identidad nacional es un concepto «de frontera» que presenta innegables problemas de concreción y dificultades, quizás insalvables, para hacerlo operativo como concepto jurídico que pueda ser objeto de aplicación jurisdiccional, de ahí que esta otra dimensión de la identidad nacional quizás permita dotarla de contenido, insertándola en una relación normalizada de confluencia entre ordenamientos jurídicos, que desactive su potencial político perturbador para el proceso de integración europea.

\section{RAFAEL BUSTOS GISBERT}

De nuevo, en las respuestas anteriores ya está apuntada mi posición. Debemos partir de que el sistema de control de la constitucionalidad europeo es un sistema complejo o, si se quiere, pluralista. Esto supone que debamos establecer diferentes situaciones en las que el papel de los distintos órganos va a ser variable. Con carácter general puede afirmarse que la posición de los Tribunales Constitucionales ha mutado. Al menos, parcialmente. Permanece inmutable en lo referido a sus competencias cuando no se encuentra en el ámbito de aplicación del Derecho de la UE. Pero, cuando está actuando dentro de ese ámbito ha pasado de ser el guardián único de la constitucionalidad a ser un actor cualificado en la defensa de la constitucionalidad europea. En cuanto guardián cualificado de la constitucionalidad europea deberá, por una parte, garantizar la unidad del orden jurídico aplicable desde la perspectiva del derecho nacional (renunciando al ejercicio de competencia alguna de control de constitucionalidad del Derecho de la UE, exceptuando los tratados antes de su ratificación); por otra, deberá ser uno de los garantes esenciales del respeto a los derechos fundamentales de la Carta por parte del Derecho de la UE utilizando su posición privilegiada (dentro del esquema interno de recursos en defensa de los derechos) para plantear, en su caso, las cuestiones prejudiciales de validez y/o de interpretación necesarias para asegurar que el Derecho de la UE emanado de las instituciones sea controlado por el TJUE y para supervisar que el derecho nacional en aplicación del Derecho de la UE también respeta los derechos fundamentales. Esto es, será no ya el autor del control de la constitucionalidad, pero sí un cooperador necesario para que dicho control de constitucionalidad europeo se active y sea eficaz. Por último, los Tribunales Constitucionales seguirán siendo los guardianes últimos de las esencias constitucionales que el TUE ha denominado como identidad constitucional. Si bien en este último caso, la lealtad debida a la UE exigirá a los Tribunales Constitucionales que antes de declarar que 
se produce una violación de la identidad constitucional plantee la pertinente cuestión prejudicial al TJUE que permita resolver el asunto en el nivel europeo de constitucionalidad sin provocar una suerte de rebelión contra ella.

El papel del TEDH es diferente. En ausencia de incorporación de la UE al sistema del CEDH su labor será la de una supervisión indirecta de la conformidad del Derecho de la UE con los derechos fundamentales del CEDH y, en cuanto la CDFUE los reconoce como propios, también de la UE. En tal sentido, a diferencia de lo que ocurre con la jurisdicción constitucional, al TEDH le corresponde trazar las líneas rojas que el Derecho de la UE no puede traspasar. Estas líneas rojas se trazan utilizando diversas fórmulas. La primera se expresa en la versión de la doctrina Solange realizada en la Sentencia Bosphorus Air Lines c. Irlanda. El TEDH deberá estar atento para evitar que, con ocasión de la aplicación del Derecho de la UE sin margen de maniobra para los Estados miembros, se produzcan violaciones flagrantes de los derechos contenidos en el CEDH. Esta suerte de espada de Damocles suspendida sobre la cabeza de las instituciones de la UE, y muy singularmente sobre el TJUE, está pensada para situaciones excepcionales pero ha permitido un control que asegura que la protección de los derechos no habrá de ser nunca manifiestamente deficiente. Una segunda fórmula resulta muy sutil, pero está, a mi juicio, resultando muy eficaz. El TEDH en su actividad diaria determina el grado de protección de los derechos en los diferentes Estados miembros de la propia UE. Esto es, está estableciendo si los derechos contenidos en el CEDH son suficientemente respetados. Y no lo olvidemos, según el art. 52.3 CDFUE y el art. 6.3 TUE, los derechos de la CDFUE no pueden interpretarse de manera que se limiten los derechos del CEDH y éstos forman parte, en cuanto principios generales, del ordenamiento jurídico de la UE. Esto quiere decir que cuando el TEDH declara que en un determinado Estado miembro de la UE existe un problema de garantía de derechos, estará trazando un límite a la aplicación del Derecho de la UE que ésta no podrá traspasar.

La diferente posición de TEDH y Tribunales Constitucionales puede explicarse perfectamente con los conocidos casos de Melloni y Aranyosi\&Caldararu (STJUE Pau Aranyosi, C-404/15, y Robert Caldararu, C-659/15, de 5 de abril de 2016). En el primero lo planteado es la incompatibilidad entre la aplicación de una norma de la UE y la definición constitucional de un derecho. Este conflicto no puede ya resolverse con el control de constitucionalidad tradicional por lo que el TC no tiene ya la competencia para declarar la inaplicación o la reinterpretación de la norma europea para salvaguardar el derecho reconocido en el art. 24 $\mathrm{CE}$. El control de constitucionalidad europeo lo que exige es que el TC en lugar de resolver el caso de manera definitiva, active los mecanismos propios de dicho control de constitucionalidad lo que implica plantear las pertinentes cuestiones prejudiciales de validez e interpretación para establecer la conformidad de la aplicación de la norma europea con los arts. 47 y 48 de la CDFUE. Resuelto que tal aplicación al caso no supone una violación de dichos preceptos por el órgano competente para ello (el TJUE) a la instancia nacional de control de constitucionalidad solo le queda aplicar la decisión o, en casos excepcionales, considerar que tal 
solución supone una lesión cualificada de los derechos nacionales que atenta a la identidad constitucional nacional (pero en tal caso tendría que haber preguntado al TJUE también sobre la posibilidad de que tal cosa ocurriera). En el caso Aranyosi (como antes en el juego de los casos expresados en la STEDH M.S.S. c. Bélgica y Grecia, de 21 de enero de 2011 y STJUE N.S v Secretary of Stateforthe Home Department, de 21 de diciembre de 2011, C-411/10) la situación es diferente. Lo que el juez nacional se encuentra no es la violación de un derecho constitucional nacional como consecuencia de la aplicación de la norma europea. En Aranyosi el problema es que el TEDH, con anterioridad, había declarado que en Rumanía y Hungría (en la primera en algunas sentencias, en la segunda en una sentencia piloto general) las condiciones en los centros penitenciarios suponían una violación de la interdicción de tratos inhumanos y degradantes. Por tanto, en este caso el juez nacional si aplicaba la norma de la UE violaba el artículo 3 del CEDH y eventualmente el 4 de la CDFUE. Por ello, el juez nacional estará obligado a activar el control de constitucionalidad de la UE y cuestionar al TJUE sobre la conformidad de la aplicación de la norma europea con los derechos fundamentales. A su vez, éste si ha de ser coherente con el art. 6.3 TUE y con el art. 52.3 CDFUE no tendrá más remedio que aceptar la jurisprudencia sentada por el TEDH en la materia y reinterpretar (o en su caso anular) la normativa de la UE aplicable, como así ocurrió en el caso expuesto (o en el previo caso N.S.).

En fin, así como en Melloni el TJUE ordenó sin más la entrega del recurrente porque no había violación de los derechos de la CDFUE; en Aranyosi por el contrario reinterpretó la Decisión Marco para que se pudieran garantizar los derechos del recurrente a no sufrir tratos inhumanos o degradantes como consecuencia de su eventual entrega a Estados que no aseguraban el respeto a sus derechos.

Como puede observarse el papel de unos y otros tribunales es diferente. El del TEDH es trazar líneas rojas que el Derecho de la UE en su aplicación por los Estados no puede traspasar. Pero se trata de líneas rojas que se dirigen, por una parte, a los tribunales nacionales para que activen el control de constitucionalidad europeo (cuestiones prejudiciales de interpretación y de validez) y, por la otra y sobre todo, al TJUE que ha de respetar la jurisprudencia previa del TEDH por mandato del propio TUE y de la CDFUE. El papel de los Tribunales Constitucionales será simplemente el de cooperador necesario en la activación del control de constitucionalidad europeo en los casos en los que aprecie un problema de compatibilidad entre el derecho de la UE con los derechos constitucionales o con los derechos del CEDH. Aparentemente, esta posición sería idéntica al del resto de jueces y tribunales nacionales, pero la situación institucional de la jurisdicción constitucional en el seno del sistema interno de protección de los derechos hará que sea ella la pieza clave o, si se quiere, la válvula general de seguridad del sistema en cuanto jurisdicción especializada y en cuanto último tribunal nacional en materia de derechos.

Finalmente allí donde el control de constitucionalidad europeo no puede ser ejercido por el TJUE, tanto los Tribunales Constitucionales como el TEDH 
deberán ser particularmente eficaces. Me refiero al control de la constitucionalidad de los tratados que continuará estando en las manos de los Tribunales Constitucionales nacionales y que, dado el nivel de integración alcanzado, deberán extremarlo para asegurar el pleno respeto no solo a las identidades constitucionales nacionales, sino también a los valores básicos de la UE. Control que además podrá ser supervisado en el caso de los derechos fundamentales en cuanto que los tratados son actos imputables a los Estados miembros y, por tanto, controlables por el TEDH como mostró en su día el asunto Mathews c. Reino Unido.

El sistema resultante es complejo porque complejo es también el ordenamiento jurídico creado en Europa. Esta complejidad podría en parte (no totalmente) reducirse si el TJUE no hubiera perdido el rumbo (J. Martín y Pérez de Nanclares, 2015) al rechazar tajantemente el proyecto de tratado para la incorporación de la UE al CEDH. Pero el Dictamen 2/13 no deja muchas esperanzas para que esto ocurra y sin duda ello va a generar graves problemas que posiblemente el TJUE no ha previsto en su desafortunada decisión sobre esta cuestión.

\section{ASCENSIÓN ELVIRA PERALES}

La posición de los tribunales constitucionales no cambia, lo que varía es que ahora han de dejar de ser autoreferenciales y han de tomar en consideración la doctrina de los tribunales europeos. En el caso español este hecho viene facilitado por la existencia del art. 10.2 CE, pues como sabemos, desde el inicio se entendió que la referencia no alcanzaba solo a la normativa internacional correspondiente, sino también a la jurisprudencia de los tribunales internacionales que velaran por el cumplimiento de esa normativa. A ello, en el caso de la UE, se añade que su ordenamiento es aplicable internamente en los términos fijados lo que implica, de acuerdo con la aceptada doctrina del TJUE, la primacía y el efecto directo, por lo que, en diversas ocasiones, en particular vinculadas a los derechos, el TC habrá de aplicar directamente el Derecho europeo y, en su caso, plantear una cuestión prejudicial.

El TC español, más allá, de los comentados casos en los que se ha discutido la incidencia en el derecho a la tutela judicial efectiva de la ausencia de un planteamiento de una cuestión prejudicial por un órgano jurisdiccional ordinario (o de los vinculados a la euroorden), ha aplicado con frecuencia el Derecho UE. Sin ánimo exhaustivo y con referencia solo a sentencias de los últimos años: como ya hemos puesto de relieve anteriormente, el Derecho europeo está en la base de numerosos pronunciamientos del principio de no discriminación y ha sido clave en el análisis e interpretación en distintos casos, en particular los vinculados a discriminaciones indirectas o inversas (SSTC 162/2016, 110/2015, 66/2015, 71/2013, 152/2011 o 26/2011); supuestos en los que fundamenta la vulneración del derecho o la inconstitucionalidad en la vulneración del Derecho de la UE, en su caso en vulneración de doctrina del TJUE (SSTC 58/2016, 232/2015, 
212/2014, 145/2012); casos en los que se apoya en la doctrina del TJUE para reforzar su argumentación: SSTC 157/2016, 121/2016, 35/2016 (en la que prácticamente remite al Derecho de la UE), 193/2013, 114 y 19, ambas de 2013 (en las que acoge como propia la interpretación ofrecida por el TJUE), 210/2012... Incluso en algún caso, al retrotraer actuaciones, recuerda al juez la obligación de aplicar, junto con el Derecho interno, el Derecho de la UE de acuerdo con la interpretación ofrecida por el TJUE en una sentencia reciente en respuesta a cuestión prejudicial planteada por un juez español (STC 123/2010). Ese empleo fluido del Derecho de la Unión debería ser la tónica general de nuestro Tribunal y de cualquier tribunal constitucional de los Estados miembros.

Con respecto al TEDH hay que tener en cuenta distintas consideraciones: una, que el número de Estados sometidos a su jurisdicción es mucho mayor que el del TJUE y, además, lo que resulta de suma importancia, con unas disparidades de toda índole mucho mayores; esto implica que en el TEDH puede ser más frecuente optar por diferenciar en función del lugar de procedencia y optar por la aplicación de unos estándares mínimos en otros casos. La mayor homogeneidad de los Estados contribuye a que el TJUE pueda ampliar esos estándares e imponerlos de manera homogénea; sin perjuicio de que, en ocasiones, también haya de recurrir a la aplicación de esos diferentes estándares como ha hecho, por ejemplo, con la aplicación de la euroorden o asuavizar sus respuestas en función de criterios políticos.

Por otra parte, a pesar del carácter tan compresivo de la CDFUE, bastantes de esos derechos difícilmente van a entrar en el ámbito competencial de la UE y del TJUE, salvo de manera indirecta (por ejemplo, como medio para limitar los efectos de una euroorden) o como vía para poner en marcha el mecanismo del art. 7 TUE. Por el contrario, los derechos contenidos en la CDFUE suponen un catálogo más extenso que el ofrecido por el CEDH y sus protocolos, lo que incrementa el número de situaciones que propicien pronunciamientos por parte del TJUE.

También hay que mencionar la inclusión en el Tratado de Lisboa de la previsión de la firma por parte de la UE del CEDH, esa previsión como es sabido, se ha visto paralizada por el Dictamen TJUE 2/2013 de 18 de diciembre de 2014. Este Dictamen ha sido criticado al contemplarse como un intento del TJUE de conservar su primacía, pero más allá de esta apreciación (algo o mucho de eso hay), pone de relieve los problemas de diversa índole que implica la adhesión, empezando por el propio papel que debería jugar el TJUE y si se abre una vía para que este pueda pronunciarse previamente cuando exista una vulneración de derechos que afecte al Derecho de la Unión. No obstante, esa paralización no significa el fin de las 'relaciones', en general fructíferas, que han venido manteniendo los dos tribunales europeos y sobre las que tanto se ha escrito. Si el TJUE se ha servido del TEDH para la defensa de los derechos cuando no estaban expresamente reconocidos por el Derecho europeo, el TEDH se ha servido de la doctrina del Tribunal de Luxemburgo para dar un impulso a la protección de algunos 
derechos, en particular en supuestos en los que con anterioridad había invocado el margen de apreciación estatal. Dos tribunales que comparten 'clientela' y que coinciden en algunos ámbitos difícilmente pueden vivir uno de espaldas al otro.

En todo caso ha de tenerse presente el hecho de que la función del TEDH y la del TJUE son muy distintas: la del primero es la defensa de los derechos recogidos en el CEDH; la del segundo la defensa e interpretación del ordenamiento de la Unión al hilo de las cuales puede ejercer como garante de los derechos. En este sentido, hay que recordar que esa defensa tendrá, en la mayoría de los casos, un carácter meramente interpretativo, habiendo de ser los órganos jurisdiccionales internos los encargados de llevarla a la práctica y, por ello, de matizarla y de adecuarla al Derecho interno, sin perjuicio de las responsabilidades que pudieran derivarse de un incumplimiento.

De igual modo, hay que recordar el mandato del art. 52.3 CDFUE que obliga a que los derechos que contiene tengan el mismo alcance que los del CEDH y sean interpretados de acuerdo con la doctrina del TEDH (lo que por otra parte el TJ llevaba años haciendo), así lo recuerda en el asunto WebMindLicensesKft.(C-419/14).

\section{JOSÉ MARTÍN Y PÉREZ DE NANCLARES}

A nuestro entender, los Tribunales Constitucionales de los Estados miembros y el Tribunal Europeo de Derechos Humanos configuran, junto al Tribunal de Justicia de la Unión Europeo, un triángulo judicial europeo de naturaleza constitucional que exige de una cooperación efectiva. Los tres tribunales son actores judiciales con vocación constitucional que actúan sobre un mismo espacio territorial —el espacio jurídico europeo-, interpretando y aplicando tres ordenamientos jurídicos constitucionales que se encuentran superpuestos de manera multinivel (Constitucionales nacionales, tratados constitutivos de la UE y $\mathrm{CEDH}$ ) y respecto de los que resulta insatisfactorio el acercamiento tradicional basado en ideas clásicas de soberanía, Estado-nación, pirámide normativa, jerarquía normativa, etc. En este nuevo escenario jurídico se hace imprescindible construir mecanismos efectivos de cooperación judicial, tengan o no una dimensión formal. Así, la cooperación formal se puede plantear a través de mecanismos institucionalizados como la cuestión prejudicial para la interacción entre los Tribunales Constitucionales y el TJUE; la nueva previsión del Protocolo 16, para que los más altos tribunales nacionales puedan plantear su consulta al TEDH; o incluso la articulación del pronunciamiento previo del TJUE en el caso de que el TEDH conociera de un asunto sin que hubiese recaído previamente pronunciamiento del TJUE, que preveía el malogrado Acuerdo de Adhesión de la Unión al CEDH. Pero, como hemos puesto de manifiesto, la cooperación judicial puede tener también un carácter no formal, esto es, puede articularse a través de lo que podría denominarse 'diálogo judicial' entre los tres 
vértices del aludido triángulo judicial constitucional. Este diálogo es probablemente tan importante como la cooperación formal y está llamado, pues, a jugar un papel de primer orden para conseguir una convivencia jurídica pacífica entre los tres tribunales en liza con aspiración constitucional en sus respectivos ámbitos competenciales, así como para lograr que el mal llamado derecho a la 'última palabra' sea sustituido por la 'palabra final' que se pronuncie, fruto de la aludida cooperación judicial, por el tribunal competente materialmente (por su competencia) de la cuestión final de que se trate.

\section{JAVIER MATÍA PORTILLA}

La primera subpregunta ha sido ampliamente respondida en el anterior apartado de la presente encuesta, a la que nos remitimos.

En relación con el Tribunal Europeo de Derechos Humanos, lo primero que debe señalarse es que éste presenta, en la actualidad, una novedosa importancia para el Estado español. A partir del momento en que se ha dificultado la admisión del recurso de amparo (con la introducción del requisito de la especial trascendencia constitucional, ex Ley Orgánica 6/2007), alcanza un renovado interés el papel de garante desempeñado por el Tribunal de Estrasburgo.

Además, el parámetro del control ejercido por el Tribunal Europeo de Derechos Humanos en el territorio de la Unión Europea es homogéneo, en la medida en que las autoridades de todos los Estados miembros ésta están obligados a respetar los derechos humanos recogidos en el Convenio tanto cuando actúan en el marco del Derecho de la Unión como cuando lo hacen aplicando Derecho interno. $\mathrm{Y}$ de este dato se podrían extraer dos importantes lecciones para el futuro de la protección de los derechos fundamentales de la Unión.

La primera es que resulta conveniente la rápida adhesión de la Unión Europea al Convenio Europeo de Derechos Humanos. No nos resulta posible valorar con detalle, como se ha hecho en un estudio previo, el borrador de acuerdo que ha sido elaborado por el Comité Director para los derechos del hombre (Consejo de Europa) y la Comisión (Unión Europea), pero bastará con decir que el resultado final era inteligente en su concepción y acertado en su contenido. Por este motivo resulta especialmente desafortunado el Dictamen 2/13 del Tribunal de Justicia, de 18 de diciembre de 2014, que lo declara incompatible con el artículo 6.2 y el Protocolo 8 TUE. Lo es porque, salvo una actuación contundente de los Estados - a través de la reforma del Tratado y la inmediata adhesión-, no impedirá que el Tribunal de Estrasburgo pueda controlar el respeto de los derechos humanos que tenga su origen en actos comunitarios, lo que, paradójicamente, situará a la Unión en una situación de indefensión que se podría haber evitado.

La segunda consideración que debe realizarse es que el Tribunal de Justicia debe, cuando ello sea posible, tomar en consideración el parámetro establecido por 
el Tribunal de Estrasburgo para determinar el contenido y alcance de los derechos fundamentales de la Unión Europea. El caso Melloni es un buen ejemplo de esta carencia. El hecho de que el Tribunal de Justicia se limite a respaldar el tenor literal de la Decisión Marco, señalando que debe darse una u otra condición (el interesado fue citado al proceso o contó con asistencia letrada), en vez de señalar, como hace el Tribunal de Estrasburgo (y respalda nuestro Tribunal Constitucional), que una y otra son presupuestos necesarios y acumulativos, deja entreabierta una puerta a posibles impugnaciones en el futuro. Demostraría criterio y habilidad el Tribunal de Luxemburgo si se anticipara a estos problemas asumiendo el parámetro previsto por el Tribunal de Estrasburgo, por ser éste razonable.

Somos conscientes de que puede ocurrir que tal extrapolación no sea siempre posible, porque los derechos fundamentales de la Unión se garantizan, es bueno no olvidarlo, «en el marco de la estructura y de los objetivos de la» Unión Europea (STJUE de 17 de diciembre de 1970, 11/70, considerando 4). Es probable, por ejemplo, que la libre circulación no pueda tener el mismo contenido en el interior de un Estado (art. 19 CE) que en el territorio de la Unión Europea (artículos 3.2 TUE t 21 TFUE y Títulos IV y V TFUE). Pero estas singularidades no están presentes en otros muchos campos y, en esos casos, el Tribunal de Luxemburgo debería tomar en consideración la jurisprudencia del Tribunal de Estrasburgo en la materia porque, de esta forma, se evitarían eventuales conflictos de futuro.

En definitiva, el Tribunal Europeo de Derechos Humanos es una garantía de que los Estados no pueden alejarse en exceso, ni directamente, ni mediante su implicación en organizaciones internacionales, de los valores directamente vinculados con el Estado constitucional. Si este control es conveniente cuando las principales decisiones de los Estados democráticos se originan en Parlamentos nacionales en los que se encuentran representadas las minorías, lo es mucho más para evaluar decisiones adoptadas por los Gobiernos de los Estados miembros en el plano internacional y de la Unión Europea.

\section{JUAN LUIS REQUEJO PAGÉS}

Contestado en las respuestas dadas a la pregunta 3.

6. ¿Considera que sería conveniente reformar la Constitución para recoger expresamente la participación de España en la UE y las consecuencias que derivan de ella?

\section{FRANCISCO BALAGUER CALLEJÓN}

En efecto, incorporar a la Constitución un perfil claramente europeísta con preceptos que se muevan dentro de eso que Peter Häberle llama el «Derecho 
constitucional europeo nacional», es decir las cláusulas sobre Europa de las constituciones de los Estados miembros, sería algo muy positivo. Hay que recordar que la reforma del artículo 135 de la Constitución incorpora una visión negativa de Europa porque va unida a las limitaciones presupuestarias que están afectando a los derechos de la ciudadanía. Por otro lado, la comparación entre la Constitución Española y los últimos Estatutos de Autonomía reformados nos da cuenta de una vocación europeísta muy marcada en los Estatutos (donde antes no había ninguna referencia a Europa o a la Unión Europea en su formulación originaria ahora hay más de cincuenta referencias en algunos de ellos) que contrasta con la práctica ausencia formal de la Unión Europea como proyecto político común en la Constitución Española. La construcción de Europa no se podrá hacer solamente desde las instituciones europeas sino que requiere un esfuerzo compartido y, por tanto, una definición europeísta de las constituciones internas, no solamente a nivel de principios sino también asumiendo las consecuencias que se derivan de la integración en el ámbito institucional o en la modulación de los procedimientos de reforma constitucional, por ejemplo.

\section{RAFAEL BUSTOS GISBERT}

A la vista de las respuestas anteriores resulta evidente que es más que conveniente reformar la Constitución e incluir una cláusula europea. De hecho suscribo plenamente la redacción, fruto de nuestras largas discusiones sobre el asunto, propuesta en esta misma encuesta por mi colega y amigo José Martín y Pérez de Nanclares.

Una cláusula de este tipo permitiría desarrollar tres funciones creo que esenciales para fortalecer la constitucionalidad del proceso de integración europeo.

En primer lugar, contribuirá a dotar de más legitimidad al propio proceso de integración. Una decisión constituyente clara a favor de la unidad europea es tanto más necesaria cuanto mayor es la influencia de aquella en la propia Constitución. Como se ha tenido ocasión de apuntar, esta influencia no ha producido solo mutaciones constitucionales concretas, sino una auténtica transformación constitucional. Conferir valor constitucional a tales transformaciones creo que sería extraordinariamente conveniente a la vez que limitaría posibles regresiones en un momento histórico en que éstas parecen proliferar con diferentes nombres y orientaciones ideológicas.

En segundo lugar, permitiría construir desde un punto de vista sustantivo, pero también desde un punto de vista procedimental, un discurso constitucional europeo en el nivel estatal. Garantizar la participación de las entidades territoriales, del Parlamento y asegurar la rendición de cuentas gubernamental por las posiciones defendidas en la Unión sería una manera razonable de afrontar la necesaria democratización del proceso interno de adopción de decisiones vinculadas a la Unión. Si además incluimos los valores sustantivos de esta forma de ejercicio 
del poder habremos dado un buen paso en la dirección de limitarlo tanto extendiendo la división de poderes como los límites al ejercicio del poder. Características consustanciales a la propia idea de constitucionalismo.

En tercer lugar, deben existir normas que garanticen lo que Cruz Villalón (La Constitución inédita, 2004), denomina la metaconstitucionalidad recíproca; esto es normas al máximo nivel normativo que aseguren la coherencia en la intersección entre el ordenamiento nacional y el ordenamiento de la Unión. Esta necesidad es, tanto mayor como consecuencia de la introducción del concepto de identidad constitucional en el art. 4.2 TUE en la medida en que una cláusula europea contribuiría, en mi opinión, a fijar cuáles son los límites de la integración $\mathrm{o}$, si se quiere en sentido positivo, cuáles son los elementos conformadores de la identidad constitucional en España.

\section{ASCENSIÓN ELVIRA PERALES}

Resulta llamativo que más de treinta años después de que España se integrara en las Comunidades Europeas (ahora la Unión Europea) nuestra Constitución no recoja ninguna alusión a la misma, más aún si se tiene en cuenta que las dos reformas acaecidas hasta el momento (art. $13.2 \mathrm{y}$ art. 135CE) fueron provocadas por exigencias de la UE, si bien la primera como consecuencia de la discrepancia observada por el TC ente la Constitución y el nuevo Tratado de la Unión Europea que quería aprobarse.

La Constitución debería recoger la participación de España en la UE, sus implicaciones y límites de forma similar a como lo han hecho otras constituciones europeas (por ejemplo, o art. 23 LFB, 88 C Francesa), y a como en su día señaló el Consejo de Estado en el Informe sobre la reforma constitucional y los debates que le acompañan (Consejo de Estado-CEPC, 2006).

Si el art. 93 CE se incluyó previendo ya la incorporación de España a las Comunidades Europeas (para lo que resultaba suficiente), salta a la vista que la situación de las Comunidades en 1985, año de la firma del Tratado de Adhesión, no es la misma que la que ha ido produciéndose con posterioridad, a partir precisamente del Tratado de Maastricht que supuso una considerable ampliación de competencias a favor de la Unión Europea, que no ha hecho sino aumentar con los tratados sucesivos. Si en 1985 la fórmula «cesión del ejercicio de competencias derivadas de la Constitución» servía para enmarcar las competencias que asumían las Comunidades Europeas, posteriormente ya no puede hablarse solo de 'ejercicio de competencias', puesto que son las propias competencias las cedidas, a la par que la voz de cada uno de los Estados ha perdido peso al haber ido disminuyendo el número de materias en las que se requiere unanimidad y crecido, por el contrario, aquellas en las que se requiere mayoría, aunque sea cualificada en buena parte de los casos.

Cabe afirmar que la adhesión de España a las Comunidades Europeas, en particular a partir de la creación de la Unión Europea, ha supuesto una mutación 
constitucional, pues ha incidido sobre el ámbito de la soberanía, en el equilibrio entre los distintos poderes y el papel de cada uno (mayor peso del Gobierno por su participación en el Consejo y en el Consejo Europeo, la labor de los jueces obligados a aplicar dos ordenamientos...), y sobre el reparto competencial entre Estado y Comunidades Autónomas.

La Constitución debería recoger la pertenencia a la Unión Europea, la incidencia de las competencias europeas en el ámbito competencial interno, la exigencia de control de la actividad europea del Gobierno, el alcance de la participación de las CCAA en la Unión, así como, en su caso, los límites. La inclusión de un precepto dedicado a la Unión Europea seguramente serviría también para poner de relieve a los ojos de los ciudadanos la importancia de la Unión y la íntima vinculación con el orden constitucional.

Una reforma constitucional para incluir la referencia a la Unión europea en sí seguramente no contaría con oposición; no obstante, si podría plantear dificultades un acuerdo sobre el texto concreto si quisieran incluirse aspecto que afectaran al reparto competencial o a la participación de las comunidades autónomas. A ello se suman los obstáculos generales a una reforma de la Constitución que, sin embargo, tantas voces demandan, en particular entre los especialistas.

\section{JOSÉ MARTÍN Y PÉREZ DE NANCLARES}

Sí, sin duda. La inclusión del artículo 93 en la Constitución de 1978 fue un acierto evidente y ha servido de base jurídica para articular la adhesión de España a la Unión e ir autorizando la celebración de sucesivos tratados de reforma de los tratados constitutivos mediante los que se han atribuido a la Unión el ejercicio de un número creciente de competencias nacionales. Ahora bien, transcurridas ya tres décadas de pertenencia de España a la Unión, la cláusula europea de nuestra Constitución da muestras evidentes de cierto agotamiento y reclama claramente una actualización, como bien recordó el propio Consejo de Estado en su Informe sobre modificaciones de la Constitución española (E-1/2005, de 16 de febrero de 2016, pp. 40 a 127; igualmente voto particular de D. Manuel Diez de Velasco, pp. 351-357).

A este respecto, nos permitiremos ofrecer a título de simple ejemplo una propuesta articulada de posible nueva regulación. Ella trae causa mediata de largas discusiones y numerosas sugerencias del competente colega salmantino y buen amigo Rafael Bustos Gisbert, a la vez que tiene como antecedente inmediato los trabajos (discretos pero intensos) dirigidos por el anterior Ministro de Asuntos Exteriores y de Cooperación, José Manuel García-Margallo a las que, por cierto, se refiere en su libro Todos los cielos conducen a España (Planeta, Barcelona, 2015). Así, sugeriríamos la inclusión de un título nuevo con el epígrafe «De la pertenencia de España a la Unión Europea», que incluiría tres artículos fundamentales, dedicados respectivamente a los principios generales (art. 1), el papel 
de los poderes del Estado (art. 2) y al papel de las Comunidades Autónomas (art. 3). Ello podría, además, venir acompañado de una referencia en el título preliminar al proceso de integración europea y, al menos, a los principios básicos de lealtad y subsidiariedad.

a) Los principios generales. Por lo que concierne al precepto sobre los principios generales, creemos que podría estar integrado por cinco apartados. El primero habría de recoger con carácter general la referencia preliminar de la pertenencia de España a la UE en igualdad con el resto de Estados miembros, así como una alusión a su articulación conforme a las normas de la Constitución y del Derecho de la Unión. El segundo aludiría a los valores y principios fundamentales, que en el fondo son los recogidos en los artículo 2 y 5.2 TUE y en la propia Constitución. El tercero incluiría el reconocimiento expreso de los principios básicos del Derecho de la Unión y podría, quizá, resultar interesante plantear la inclusión también de una suerte de cláusula de intangibilidad para dar respuesta al debate jurisprudencial actual sobre los límites de la atribución de competencias; pero habría que calibrar concienzudamente la formulación de la misma. En su redacción, al referirse con carácter general a España quedaría claro que la obligación concierne a todos los poderes del Estado, con lo cual se solventaría la actual omisión del apartado segundo del artículo 93 en relación con el poder judicial. Obviamente quedan también incluidas las Comunidades Autónomas. De todas formas, si se desease ser más explícito, ya sea en este precepto o ya fuere en un apartado añadido al artículo 2.1, se podría establecer que «todos los poderes del Estado estarán obligados a garantizar el cumplimiento de las obligaciones derivadas de dichos tratados, así como de las normas aprobadas por la Unión en ejercicio de las competencias que le hayan sido atribuidas». El cuarto apartado se dedicaría a la Carta de Derechos Fundamentales de la UE, ya que, dada su trascendencia en las relaciones entre los ordenamientos constitucionales en liza (constitucional, Derecho de la UE y $\mathrm{CEDH}$ ) no estaría de más su referencia expresa en la Constitución. Y, finalmente, el último apartado incluiría el principio de lealtad entre el Estado y las CCAA al elaborar y aplicar el Derecho de la Unión. Su redacción, por tanto, podría ser la siguiente:

\section{Articulo 1 (Principios generales)}

1. España participará lealmente en la Unión Europea en condiciones de igualdad con el resto de sus Estados miembros de acuerdo con las normas previstas en la Constitución y en el Derecho de la Unión.

2. La participación de España en la Unión Europea contribuirá al progreso del proceso de integración europea con respeto de los valores de la dignidad humana, la libertad, la democracia, la igualdad, el Estado de Derecho, la subsidiariedad y la adecuada garantía de los derechos fundamentales, así como de los valores superiores consagrados en esta Constitución. 
3. España reconoce los principios del ordenamiento jurídico de la Unión Europea y garantiza el cumplimiento de las obligaciones derivadas del mismo, [si bien ello no supondrá un cambio sustancial en los principios básicos formulados en el título preliminar de la Constitución].

4. La Carta de Derechos Fundamentales de la Unión Europea resulta vinculante para España en el ámbito de aplicación del Derecho de la Unión.

5. Las Comunidades Autónomas y el Estado colaborarán lealmente en los asuntos relacionados con la elaboración y ejecución del Derecho de la Unión Europea.

b) El Papel de los poderes del Estado. A continuación, un segundo precepto haría referencia al papel de los poderes del Estado. Este podría incluir cuatro apartados. El primero recogería el núcleo fundamental del actual artículo 93 a propósito de la autorización de las Cortes Generales para la celebración de tratados por los que se atribuya a la Unión el ejercicio de competencias derivadas de la Constitución. Se eliminaría, así, la exigencia formal de Ley Orgánica y se introduciría una referencia expresa a la Unión. Dada la desaparición de la actual alusión genérica a que «mediante ley orgánica se podrá autorizar la celebración de tratados internacionales que atribuya a una organización o institución internacional el ejercicio de competencias derivadas de la Constitución», convendría plantearse si resulta pertinente incluir en el artículo 94.1 un nuevo apartado en relación a la atribución de competencias derivadas de la Constitución a organizaciones internacionales diferentes a la Unión Europea (hasta ahora tan sólo se ha empleado en el artículo 93 para autorizar la celebración del Estatuto de Roma, por el que se crea la Corte Penal Internacional). Cabe plantearse, igualmente, si convendría introducir alguna referencia a la posibilidad/obligación de celebrar algún referéndum previo a la autorización de las Cortes Generales, si bien esta es una cuestión más de índole política que realmente jurídica. No obstante, en nuestra personal opinión, caso de considerarse pertinente, no debería articularse en ningún caso como una obligación, sino como una posibilidad. El segundo apartado, establece el control del Gobierno por las Cortes Generales en los asuntos de la UE. En este sentido, según fuera el modelo del Senado por el que se optara, suponiendo que finalmente se afrontase también la sempiterna cuestión de la necesaria reforma del Senado, se podría precisar su papel en relación con las actuaciones de la Unión que afecten directamente a competencias de las Comunidades Autónomas. Lógicamente, su articulación práctica sería bien diferente según se decantase la reforma constitucional por un Senado de corte Bundesrat (representantes de los gobiernos de las Comunidades Autónomas) o por un Senado de perfil parlamentario (representantes de los parlamentos regionales) o cualquier otro. El tercer apartado recogería la exigencia de que el Gobierno informe sin dilación a las Cortes Generales de los asuntos relativos con la Unión. Y el cuarto apartado trataría de mitigar la actual omisión del apartado segundo del artículo 93, e incluiría la previsión de que (también) el poder judicial vele la correcta interpretación y aplicación del Derecho de la Unión. 
Su redacción, por tanto, podría ser la siguiente:

\section{Artículo 2 (Papel de los poderes del Estado)}

1. Las Cortes Generales podrán autorizar, por mayoría absoluta de las dos cámaras, la celebración de tratados por los que se atribuya a la Unión Europea el ejercicio de competencias derivadas de la Constitución. [Posibilidad de referéndum].

2. Las Cortes Generales ejercerán el control del Gobierno sobre los asuntos de la Unión Europea. Antes de la adopción de los actos normativos de la Unión las Cortes Generales podrán expresar su parecer, debiendo ser tenido en cuenta por el Gobierno en su posición negociadora.

3. El Gobierno informará sin dilación a las Cortes Generales de los asuntos relacionados con la Unión Europea, debiendo justificar adecuadamente los motivos de su posición en caso de que por razones imperiosas se hubiera apartado de la posición negociadora previamente fijada por las Cortes Generales. Igualmente, ejercerá las acciones pertinentes ante el Tribunal de Justicia de la Unión Europea cuando considere que concurren las circunstancias pertinentes para ello [y, en todo caso, cuando así se lo soliciten las Cortes Generales por mayoría del pleno del Congreso de los Diputados y del Senado].

4. El poder judicial velará por la correcta interpretación y aplicación del Derecho de la Unión Europea y cooperará con el Tribunal de Justicia de la Unión Europea en los términos previstos en los tratados constitutivos de la Unión.

c) La participación de las CCAA. Finalmente, un tercer precepto iría dedicado a regular la participación de las CCAA en los asuntos europeos. Este tendría igualmente cinco apartados.

En el primero de ellos, podría preverse el principio general de participación de las CCAA en la formación de la voluntad del Estado en asuntos europeos y en la ejecución del Derecho de la Unión. A este respecto, por la que afecta a la participación en la formulación de la voluntad del Estado, la cuestión de precisar el alcance material de las competencias sobre las que debe darse la referida participación de las Comunidades Autónomas resultará controvertida. Habrá que buscar, a la postre, un equilibrio entre la opción (autonómica) de hacerlo cuando se vea afectada cualquier tipo de competencia o (incluso) interés legítimo de la Comunidad Autónoma y la posible opción (estatal) de limitarlo a las competencias exclusivas. Debe, en todo caso, tenerse en cuenta que, por ejemplo, el artículo 184 del Estatuto de Autonomía de Cataluña se refiere de manera muy amplia a todas las competencias o intereses ( $\mathrm{La}$ Generalitat participa, en los términos que establecen el presente Estatuto y la legislación el Estado, en los asuntos relacionados con la Unión Europea que afecten a las competencias o los intereses de Cataluña»). Es, en todo caso, una cuestión cuya resolución está de nuevo íntimamente ligada con la opción de reforma del Senado por la que se opte; si se optase por una reforma tipo Bundesrat podría ser la sede más adecuada para conformar la voluntad del Estado en la materia; de lo contrario habría que estudiar con cuidado su interacción con las Conferencias Sectoriales y la Conferencia dedicada a los 
Asuntos de la Unión Europea. Por otro lado, en relación con la ejecución del Derecho de la Unión por las CCAA, además de las previsiones en los Estatutos de Autonomía (ej. art. 189.1 Estatuto de Cataluña), también el Tribunal Constitucional ha reconocido «la competencia autonómica para adoptar las disposiciones necesarias en complemento del Derecho comunitario europeo y para ejecutar y aplicar en su ámbito territorial normativa comunitaria siempre que, rationemateriae, las Comunidades Autónomas ostenten esa competencia y no rebasen la linde establecida por la normativa comunitaria y la estatal básica o de coordinación» (STC 95/2002, de 25 de abril, FJ 2). Obviamente, habría que tener en cuenta esta consideración.

El segundo apartado recogería la presencia de representantes de los gobiernos autonómicos en las delegaciones españolas en la UE. Con ello, se trata de plasmar, con una formulación suficientemente genérica para no comprometer cambios futuros, la realidad ya existente de participación de representantes de las CCAA en los grupos de trabajo de la esfera de la Comisión y el Consejo, así como en determinadas formaciones del Consejo (Acuerdo del Congreso de los Diputados de 10 de marzo de 1998, BOCG, Congreso, Pleno, VI Leg., n. ${ }^{\circ} 140$, p. 7382; Acuerdo entre el Gobierno y las CCAA, de 9 de diciembre de 2004).

El tercer apartado establecería la participación de los parlamentos autonómicos en el control de la aplicación de los principios de subsidiariedad y proporcionalidad. Esta disposición es conforme tanto con la previsión del Protocolo n. ${ }^{\circ} 2$ del TUE, sobre la aplicación de los principios de subsidiariedad y proporcionalidad, que prevé la posible participación de los parlamentos regionales en el control ex ante de la subsidiariedad (art. 6), como con las disposiciones incluidas en algunos Estatutos de Autonomía (ej. art. 188 Estatuto de Cataluña). La práctica actual a través de la Comisión Mixta Congreso-Senado también incluye esta participación dentro del periodo de 8 semanas dado a los parlamentos nacionales por el citado Protocolo n. ${ }^{\circ} 2$ para expresar su posición. Cabe, en cualquier caso, plantearse la pertinencia o no de incluir un precepto de este tipo ya que se trata de un mecanismo que depende de la propia Constitución y que podría modificarse en reformas futuras de los tratados constitutivos, con lo cual la previsión constitucional quedaría obsoleta.

El cuarto apartado se referiría a la posibilidad de las CCAA de solicitar al Gobierno el ejercicio de acciones judiciales ante el TJUE. Esta disposición daría cobertura constitucional a uno de los elementos esenciales plasmados en el Acuerdo de 11 de diciembre de 1997 sobre los procedimientos ante el Tribunal de Justicia (BOE de 2 de abril de 1998). Afecta lógicamente a los recursos de anulación (art. 263 TFUE) y de omisión (art. 265 TFUE). Lógicamente ello no es óbice para que en el plano infraconstitucional existan otros Acuerdos que, al estilo del celebrado en 1990, regulen por ejemplo los aspectos relativos a los procedimientos precontenciosos de la Comisión.

Finalmente, el último apartado recogería la manera de establecer la forma y condiciones de la participación establecida en los apartados anteriores. Se opta 
por la vía del convenio de colaboración entre el Gobierno y las CCAA con el refrendo de las Cortes Generales. De todas formas, cabe también la posición de que esta colaboración se regule mediante ley, si bien el mecanismo del 'Convenio de Colaboración' da mejor muestra de una adecuada cooperación vertical entre el Estado y las Comunidades Autónomas. Plantea, con todo, problemas jurídicos de diversa índole que deberían ser analizados, especialmente por lo que concierne a la pertinencia de regular mediante este Convenio (de naturaleza jurídica no legislativa) la participación de los parlamentos regionales.

Así, por tanto, su formulación podría ser la siguiente:

\section{Art. 3 (Participación de las CCAA)}

1. Las Comunidades Autónomas participarán en la formación de la voluntad del Estado en asuntos europeos cuando se vean afectadas sus competencias (exclusivas) o sus intereses singulares, así como en la ejecución y aplicación del Derecho de la Unión Europea en los términos previstos en sus respectivos Estatutos de Autonomía.

2. Representantes de los gobiernos de las Comunidades Autónomas podrán formar parte de las delegaciones españolas en la Unión Europea.

3. Los Parlamentos de las Comunidades Autónomas participarán en el mecanismo de control de la aplicación de los principios de subsidiaridad y proporcionalidad cuando en el ejercicio de competencias no exclusivas de la Unión se vean afectadas competencias legislativas de las Comunidades Autónomas.

4. Las Comunidades Autónomas podrán solicitar al Gobierno el ejercicio de acciones judiciales ante el Tribunal de Justicia de la Unión Europea, pudiendo el Gobierno rechazar la solicitud cuando así lo aconsejen razones (imperiosas) debidamente justificadas.

5. La forma y condiciones de la participación prevista en los apartados anteriores se fijarán en un Convenio de colaboración entre el Gobierno y las Comunidades Autónomas, que deberá ser refrendado por las Cortes Generales.

\section{JAVIER MATÍA PORTILLA}

Sí, claro. Parafraseando al profesor Cruz Villalón, así como un jurista persa que leyera (¡todavía hoy!) nuestra Constitución no podría entender la organización territorial del poder en España, tampoco sabría nada de nuestra implicación en un proyecto político europeo que, como ya se ha indicado, afecta a nuestras principales estructuras constitucionales (como hemos hecho notar en la pregunta 3). Podría partirse, para ello, de la sugerencia contenida en el Informe del Consejo de Estado sobre modificaciones de la Constitución española (2006).

Si así fuera, podrían contemplarse normas procedimentales (para la ratificación de los futuros Tratados vinculados con la Unión Europea) y otras sobre las consecuencias que nuestra presencia en la Unión Europea tiene para nuestro Estado. 
En relación con estas últimas, que se recogen expresamente en el enunciado de este interrogante, deberían de plasmar la aceptación limitada del principio de primacía del Derecho de la Unión. Así se hace en la citada propuesta, en la que se señala, de un lado, que dicha implicación se realiza «sin mengua de los principios consagrados en el Título Preliminar» y en una unión «comprometida con el Estado de Derecho, la democracia y los derechos fundamentales» (apartado primero del nuevo artículo a incorporar en la Constitución), y se afirma, de otro, que «los tratados de la Unión Europea y las normas emanadas de sus instituciones en el ejercicio de sus competencias serán aplicables en España en los términos definidos por el propio Derecho de la Unión» (apartado tercero).

En esta formulación se encierra, inevitablemente, la apertura del Derecho Constitucional al Derecho de la Unión, que es muy generosa pero limitada a la vez. Es una tensión con la que tenemos que convivir y que solamente será pacífica si todos los poderes públicos implicados (de la Unión y de los Estados miembros) son sensatos en sus actuaciones.

No podemos abandonar esta pregunta sin realizar dos consideraciones suplementarias, que van más allá del interrogante formulado.

La primera es que aunque la reforma constitucional resulta urgente por otras razones más poderosas (como es el cierre del modelo autonómico), es posible que no corran ahora buenos tiempos para afrontar tal reto de forma sosegada. Lo relevante es subrayar, en el contexto de este trabajo, que las cláusulas europeas presentes en otras Constituciones de nuestro entorno no han evitado que sus Tribunales Constitucionales (especialmente, como ya se ha visto, el alemán) se hayan visto obligados a recordar los límites del proceso europeo de integración. Esto nos permite concluir que estamos ante una reforma conveniente pero no imprescindible.

La segunda consideración que queremos realizar es que resulta erróneo entender que los principales retos que presenta nuestra democracia (corrupción, falta de lealtad institucional, incapacidad para la coordinación administrativa, etc.) se solventarán con la reforma de la Constitución o de otras normas jurídicas. A nuestro juicio estos problemas tienen su origen en algo más profundo, que es la falta de cultura constitucional (Cruz Villalón), que solamente se remediará a través de una redefinición de nuestro sistema de valores, a través de una ambiciosa reforma educativa. Obviamente, esta hipótesis escapa claramente al contenido de la encuesta, por lo que nos limitamos a dejarla aquí apuntada.

\section{JUAN LUIS REQUEJO PAGÉS}

No sé qué se ganaría con ello. Si lo que se pretende es la definición clara de competencias, es un ejercicio inútil, por imposible. Me parece que los artículos 93 a 96 CE han sido suficientes para permitir la integración de España en la Unión de una manera razonable. Queda siempre, claro está, la tentación de la 
claridad y del sistema, la idea de que sería conveniente establecer en la Constitución un modelo acabado y perfecto de articulación del Derecho interno con el Derecho de la Unión. Por encomiable que sea esa aspiración en otros terrenos, en el ámbito de la integración europea sería una tentación temeraria.

La relación entre el Derecho de la Unión y los Derechos nacionales está basada en un equívoco interesado. Deshacerlo sería tanto como hacer impracticable la integración misma. El Derecho nacional parte del principio de la supremacía de la Constitución, que en sus justos términos significa que la constitucionalidad es una condición exigible a cualquier norma (nacional o foránea) que pretenda integrarse en el ordenamiento interno. El Derecho de la Unión parte del reconocimiento de la soberanía de los Estados miembros y, por tanto, de la supremacía de sus respectivas Constituciones nacionales. Lejos de reconocerse la condición de soberano $-\mathrm{y}$, por tanto, la titularidad de una competencia originaria y universal—, la Unión se concibe como sujeto titular de competencias atribuidas por los verdaderos soberanos.

A partir de estos postulados, las contradicciones entre el Derecho de la Unión y el Derecho nacional debieran resolverse siempre en beneficio de la supremacía constitucional. La Constitución no admite contradicción, ni siquiera por parte de normas integradas en el ordenamiento nacional en virtud de una «cláusula de apertura» incorporada a la propia Constitución (art. $93 \mathrm{CE}$ ), pues la apertura encuentra siempre un límite en el respeto a la supremacía misma de la Constitución.

De ser así las cosas, el Derecho de la Unión se disolvería en el seno de los Derechos nacionales, perdiendo la autonomía mínima necesaria para asegurar su identidad. La identidad del Derecho de la Unión se garantiza en virtud del principio de primacía. Sin ponerse con él en cuestión la supremacía de las Constituciones nacionales, se asegura para las normas de la Unión una posición que, sin ser formalmente supraconstitucional, las sitúa materialmente por encima de la Constitución. Desde el punto de vista jurídico-formal, la supremacía de la Constitución está perfectamente garantizada. Desde el punto de vista jurídico-material o práctico, queda asegurada la preeminencia del Derecho de la Unión.

El lenguaje jurídico-formal de las Constituciones y de los Tratados se refiere a una realidad desmentida por la lógica del principio de primacía. Si lo primero permite a los Estados miembros cierta tranquilidad en cuanto a su soberanía (formal), lo segundo permite a la Unión comportarse como un soberano (material). De la indiferenciación interesada entre lo formal y lo material nace el equívoco sobre el que se articulan las relaciones entre la Unión y los Estados. Un equívoco que permite a éstos la ilusión de la soberanía y a aquélla la eficacia de un poder incontestable ( $\mathrm{y}$, por ello, a la postre, soberano).

La DTC 1/2004 representa un intento de conciliar en términos jurídico-formales la contradicción inherente al binomio supremacía/primacía. Se trata, sin embargo, de una contradicción insuperable.

El despliegue de la lógica del principio de primacía en el ámbito de los derechos fundamentales pone de manifiesto que la tensión primacía/supremacía 
encubre, en realidad, una disputa por la soberanía entre quienes siguen siendo soberanos (Estados) y quien pretende llegar a serlo (Unión). Una disputa que sólo puede resolverse definitivamente en beneficio de un solo soberano (Hobbes) y que, en tanto no se resuelva (con el triunfo - excluyente- de los Estados o de la Unión), obligará a perseverar en la impostura del equívoco sobre el que se ha construido desde un principio el proceso de la integración europea.

Ninguna Constitución puede traducir en términos jurídico-formales la realidad jurídico-material que subyace al proceso de integración. De hacerlo, estaría renunciando a su condición misma de norma constitucional, esto es, de manifestación positiva de una voluntad soberana. Esa traducción sólo será factible en una Constitución de Europa.

7. Sin perjuicio de lo anterior, a la vista de la dimensión de la Carta de derechos fundamentales y de la categoría de «la ciudadanía de la Unión» ¿estima que la Unión al ser garante de los derechos fundamentales avanza efectivamente en la creación de un espacio común de protección de los derechos? ¿Ha incorporado en su estructura —el TJUE incluido-un factor de expansividad competencial al que será muy difícil poner otro limite que el que autoadapten el TJUE y las restantes instituciones de la propia UE? ¿El TJUE se ha convertido en un factor de la constitucionalidad de los Estados miembros?

\section{FRANCISCO BALAGUER CALLEJÓN}

En mi opinión, la Carta de los Derechos Fundamentales de la Unión Europea es el principal factor de la construcción constitucional de Europa. La ciudadanía europea como concepto constitucional sigue sin ser realmente operativo porque tenemos todavía en el nivel político una ciudadanía marcadamente nacional que se proyecta sobre Europa en la defensa de los intereses nacionales. En cambio, en el nivel jurídico el concepto de ciudadanía europea se puede construir de manera más efectiva por medio de la creación de un espacio común de derechos, a través de la Carta y de la labor del TJUE y de los tribunales nacionales en su aplicación y desarrollo.

Por lo que se refiere a la dimensión competencial, en efecto, a pesar de las cautelas establecidas por el Tratado de Lisboa para impedir que la Carta pueda configurarse como un instrumento de expansión del Derecho de la Unión, lo cierto es que la vinculación directa a la Carta y especialmente la garantía del contenido esencial de los derechos que incorpora, pueden provocar una penetración cada vez mayor en los ordenamientos nacionales. En mi opinión es algo que debe valorarse positivamente porque generará una relación dialéctica que no dará lugar tanto a la expansión competencial del Derecho de la Unión cuanto a la ampliación de la esfera de los derechos fundamentales en relación con los reconocidos internamente por la Constitución nacional de cada Estado miembro. 
Por lo que se refiere al TJUE no cabe duda de que se está configurando como un factor de la constitucionalidad de los Estados miembros. Esto no es algo negativo sino que resulta un efecto inevitable de la integración supranacional y puede generar resultados positivos desde la perspectiva de una interacción productiva entre el nivel constitucional interno y el europeo. Al mismo tiempo, cabe señalar también que los tribunales constitucionales nacionales son y deben ser cada vez más un factor de la construcción de Europa interviniendo en el debate público europeo. El Derecho Constitucional Europeo debe construirse mediante la articulación en todos los niveles de la vertiente constitucional y la europea.

\section{RAFAEL BUSTOS GISBERT}

Se trata de tres preguntas diferentes que a estas alturas de la encuesta tienen una respuesta positiva claramente anunciada.

Respecto a la primera, debemos abandonar las lentes estatales (perspectiva que implica el análisis de los conceptos y categorías constitucionales solo a través de su aplicación al Estado) y ser conscientes que ese espacio común de derechos lo es en las materias atribuidas a las competencias de la Unión y no a todo tipo de materias. Es decir, la creación de un espacio común se produce sin hacer desaparecer las diferencias estatales. Sin embargo, existe una fuerte tendencia expansiva a construir ese espacio común en materia de derechos más allá de las competencias de la UE debido a las interacciones propias del contexto de complementariedad constitucional existente en Europa. Este contexto hace que la integración en materia de derechos derivada de la Unión Europea tenga una vis expansiva evidente en la construcción del propio concepto de consenso común europeo que tan a menudo usa el TEDH para avanzar o no en la ampliación de los contenidos de los derechos convencionales. Si, además, como ha ocurrido en España, la CDFUE, y la jurisprudencia del TJUE sobre ella, es considerada un tratado internacional vinculante en sentido interpretativo para dotar de contenido a los derechos constitucionales nacionales, a la vis expansiva iusinternacional habrá que sumar una vis expansiva estatal. Esto puede ser, a mi juicio, un peligro en la medida en que ahogue las posibilidades de desarrollar elementos sustantivos o discursos interpretativos propios de cada Estado que nutran y/o limiten los desarrollos en los niveles supraestatales. El espacio común de los derechos de la UE no es, ni creo que esté pensado para llegar a serlo, omnicomprensivo de todas las actuaciones públicas y privadas como sí lo eran el espacio de derechos construido constituciones estatales. Es un espacio común sólo para determinados ámbitos de actuación cuya regulación se ha estimado conveniente compartir en el marco de la propia Unión. Un espacio común que se nutre de abajo arriba (contrapuntualmente diría el Abogado General Maduro) y no al revés. Sustituir totalmente los flujos ascendentes por los descendentes (de la UE hacia abajo, del TJUE hacia los Tribunales Constitucionales) creo que resultaría empobrecedor. En fin, fuera del ámbito 
propio del Derecho de la UE la tan controvertida doctrina del margen de apreciación nacional (véase en general, J. García Roca, 2011) acuñada fundamentalmente por el TEDH debe seguir permitiendo diversas aproximaciones a la construcción de los derechos fundamentales en el seno de los Estados miembros tanto del Consejo de Europa como de la Unión Europea.

Respecto a la expansividad del modelo resultante es pronto para concluir nada al respecto, aunque parece un riesgo real de acuerdo con lo hasta aquí expuesto. La experiencia histórica demuestra que el desarrollo de procesos de este tipo en Estados federales ha implicado esa expansividad y que los límites solo los han podido fijar las instituciones de la organización federal y muy singularmente su máximo órgano judicial. Pero la UE no es un Estado federal. Los Tribunales Constitucionales tienen un papel importante que cumplir en las eventuales limitaciones a esa expansividad. El que sean o no eficaces va a depender de cómo lo ejerzan y no solo de la voluntad del TJUE. Algo parecido puede decirse respecto al resto de instituciones de la Unión. La capacidad para evitar una expansión no deseada del espacio común europeo de derechos dependerá también de la fuerza de los procesos políticos nacionales de formación de la voluntad exterior (valga europea) de los gobiernos estatales que siguen constituyendo un lugar de decisión esencial (aunque no único) en los procesos de decisión de la Unión.

Respecto a la tercera pregunta, de nuevo la respuesta ha de ser afirmativa. Pero esto debería estar muy claro desde años. Van Gend en Loos, Simmenthal, Costa c Enel, ElsVerts, Francovich no son sentencias precisamente recientes. En ellas, desde hace años, está la configuración del TJUE en cuanto guardián de un ordenamiento jurídico autónomo ajeno al control por parte de los Estados miembros. Y eso es un factor de constitucionalidad de primer orden.

\section{ASCENSIÓN ELVIRA PERALES}

Como ya hemos dicho antes, en la actualidad es difícil encontrar ámbitos no 'contaminados' por el Derecho de la UE de manera que, más allá de las competencias atribuidas, son muchas las cuestiones en las que la UE y su Derecho encuentran su ámbito de aplicación o de afectación, por solo citar algún caso el conocido asunto Ruiz Zambrano o el más reciente Rendón Marín son buena prueba de ello, en ambos por la presencia de menores ciudadanos europeos.

La CDFUE ha aumentado esa tendencia a que el TJUE pueda o deba pronunciarse sobre derechos fundamentales, pero la tendencia existía ya con anterioridad (por ejemplo, asuntos Rutili o Wachauf), la CDFUE no ha hecho más que ampliar las posibilidades de expansión y 'legitimarlas': una UE sin Carta de derechos no parecía estar en condiciones de imponer la defensa de los derechos a Estados que contaban con una fuerte tradición en este sentido, la Carta ahora lo permite.

La CDFUE cuenta con una ventaja frente a las declaraciones presentes en las constituciones: es un catálogo de derechos actual, en bastantes casos más amplio, 
y que aborda cuestiones anteriormente inexistentes como la denominada biomedicina o una declaración expresa de la protección de datos personales. Así, frente a las construcciones doctrinales que han sido necesarias para proteger nuevas situaciones o adaptarlas a los nuevos tiempos, la CDFUE integra nuevos derechos o la interpretación actualizada de derechos clásicos.

No obstante, es preciso tener en cuenta dos factores: uno, que claramente ha incidido en la doctrina del TJUE sobre el alcance de la ciudadanía europea y otro, no tan evidente, pero que condiciona igualmente las decisiones del Tribunal de Luxemburgo. Estos factores a los que me estoy refiriendo son, el primero, la crisis económica que ha acrecentado imposición de medidas restrictivas por parte de los Estados hacia los no nacionales, incluidos los ciudadanos europeos, de esta manera, si a finales de los 90 e inicios de la década del 2000 parecía que la posesión de la ciudadanía europea era la llave para una equiparación casi plena con los nacionales, a partir de mediados de la década el TJUE se ha mostrado más cauto y ha admitido la imposición de distintos requisitos (en general vinculados a la exigencia de un periodo de residencia) para alcanzar el reconocimiento de beneficios sociales. Sentencias como las de los asuntos Grzelczyk (C-184/99) o Martínez Sala (C-85/96) quizá no fueran posibles ahora; en los asuntos Dano (C-333/13) o Alimanovic (C-67/14) ya se admiten restricciones y el Abogado General Melchior Wathelet llega a preguntarse si la libertad de circulación se ha convertido en una quimera (Conclusiones presentadas el 2 de junio de 2016 en el Asunto Maria do Céu Bragança Linares Verruga, Jacinto Manuel Sousa Verruga, André Angelo Linares Verruga, C-238/15).

El segundo factor, es la crisis política dentro de la Unión (si bien en buena medida vinculada a la económica) que puede llevar a que el TJUE se muestre más cauto y ofrezca un mayor margen de decisión a los Estados para evitar movimientos contrarios a la UE, cuyo caso extremo es el que ha conducido al Brexit, pero que florece en distintos movimientos populistas y de extrema de derecha de diferentes Estados europeos (y de forma señalada en los Estados originarios de las CCEE). Si el Tribunal de Justicia ha sido el artífice de grandes impulsos a las Comunidades primero, a la Unión después, también ha sabido aplicar la contención cuando las circunstancias así parecían requerirlo.

El TJUE se ha encargado de subrayar que «sólo puede interpretar el Derecho de la Unión dentro de los límites de las competencias que le son atribuidas» y que «cuando una situación jurídica no está comprendida en el ámbito de aplicación del Derecho de la Unión, el Tribunal de Justicia no tiene competencia para conocer de ella y las disposiciones de la Carta eventualmente invocadas no pueden fundar por sí solas tal competencia» (entre otros, asuntos Torralbo Marcos, C-265/13, o Toma, C-2015/15). Es cierto que tales manifestaciones por sí solas no significan nada, pero suponen una declaración de intenciones y un intento de tranquilizar a los Estados.

Así mismo habría que tomar en consideración el difícil equilibrio que en ocasiones se plantea entre defensa de los derechos fundamentales y salvaguarda de 
los objetivos de la Unión, aspectos que no siempre concuerdan; en este sentido cabe apreciar dos posibilidades: una, la solución expresada en los conocidos asuntos Omega o Schmitberger en los que la defensa de los derechos fundamentales implicados prevalece frente a las clásicas libertades de la Unión en juego; otra, en la que la defensa de un espacio común prima sobre una mayor protección de determinados derechos, tal sería el caso precisamente del asunto Melloni.

Convendría añadir otro factor y es que el TJUE a pesar del peso que imprime la existencia de la CDFUE sigue invocando los principios generales del derecho de la Unión para proteger derechos que no resultarían protegidos por la Carta en virtud de las limitaciones que conlleva: tal es el caso del asunto Web Mind LicensesKft. (C-419/14, con cita de otros) en el que ante la no aplicabilidad del art. 41 CDFUE invoca el derecho a la defensa ante las Administraciones como principio general del Derecho de la Unión. Este tipo de interpretación muestra el afán por parte del TJUE de ejercer como auténtico guardián de los derechos.

El afán del TJUE en garantizar los derechos fundamentales en el marco de la UE, sin embargo, no tiene porqué interpretarse necesariamente como un signo de ampliación de competencias, sino que puede entenderse, por un lado, como forma de mostrar a los órganos jurisdiccionales internos, en particular a los tribunales constitucionales, su compromiso en la defensa de los derechos; por otro lado, podría interpretarse como un medio de mostrar que su respuesta negativa a la firma del CEDH por parte de la Unión Europea no implica un merma para la defensa de los derechos fundamentales.

Así mismo merece resaltar que el TJUE se ha encargado de afirmar el efecto directo de los derechos fundamentales recogidos en la CDFUE, al igual que el resto del derecho de la Unión, precisando que «el Derecho de la Unión se opone a una práctica judicial que supedita la obligación del juez nacional de no aplicar ninguna disposición que infrinja un derecho fundamental garantizado por la Carta al requisito de que dicha infracción se deduzca claramente del texto de dicha Carta o de la jurisprudencia en la materia, dado que priva al juez nacional de la facultad de apreciar plenamente, con la cooperación del Tribunal de Justicia en su caso, la compatibilidad de dicha disposición con la Carta» (Asunto $\AA$ kerberg Fransson, C-617/10). La precisión resulta importante pues resalta la declaración contenida en el Tratado de Lisboa de los plenos efectos jurídicos de la CDFUE, sin que pueda considerarse un mero complemento de los tratados. Supone también apoderar a los jueces en la defensa de los derechos.

Sin embargo, ante esas amenazas y las violaciones de derechos acaecidas en varios Estados miembros, el TJUE y la Unión Europea pueden actuar como factor de estabilidad y que permita un control de los Estados infractores.

Por estos motivos, y sin perjuicio de que la invocación de los derechos fundamentales haya crecido a partir de la entrada en vigor del Tratado de Lisboa, habrá que esperar más años para comprobar cuál es la evolución, en la que la interrelación con los tribunales constitucionales (y con el TEDH) está llamada a jugar un papel destacado. 


\section{JOSÉ MARTÍN Y PÉREZ DE NANCLARES}

En nuestra opinión, la decisión de los Estados miembros de la Unión de incorporar en Lisboa la Carta a los tratados constitutivos, a través del instrumento denominado de la 'incorporación por referencia', y dotarla a la vez de carácter jurídicamente vinculante (art. 6.1 TUE) supone un importante paso adelante en la construcción de un espacio jurídico europeo en materia de derechos humanos. No creemos, sin embargo, que ello suponga en modo alguno un factor de expansión competencial en el ámbito de la Unión; y tampoco estimamos, por ello, que sea adecuado el planteamiento de poner límites a esa pretendida expansión competencial. Antes al contrario, la Carta encarna en sí misma la imposición de límites negativos claros a la actuación de las instituciones, órganos y organismos de la Unión; cualquier acto de la Unión deberá respetar, así, los límites precisos que marcan los derechos recogidos en la Carta. En realidad, ni siquiera la fijación del estándar mínimo de protección de esos derechos queda en manos exclusivas del TJUE. El artículo 52.3 deja claro que «en la medida en que la presente Carta contenga derechos que correspondan a derechos garantizados por el Convenio Europeo para la Protección de los Derechos Humanos y de las Libertades Fundamentales, su sentido y alcance serán iguales a los que les confiere dicho Convenio». Ello con independencia de que, en beneficio de los ciudadanos europeos, «no obstará a que el Derecho de la Unión conceda una protección más extensa». Pero ni aun esta posibilidad de protección comunitaria más intensa puede ser interpretada como una expansión competencial de la Unión. La propia Carta deja patente en su artículo 51.2 que la misma «no amplía el ámbito de aplicación del Derecho de la Unión más allá de las competencias de la Unión, ni crea ninguna competencia o misión nuevas, ni modifica las competencias y misiones definidas en los Tratados»; esto es, la Carta no amplía en modo alguno las competencias que los Estados han atribuido a la Unión a través de los tratados constitutivos.

A la vez, los Tribunales Constitucionales de los Estados intervienen también en la configuración interpretativa y aplicación adecuada de los derechos fundamentales por el TJUE desde el momento que el carácter vinculante de la Carta se hace compatible con el mantenimiento de los derechos que son fruto de las tradiciones constitucionales comunes a los Estados miembros como principios generales del Derecho de la Unión (art. 6.3 TUE). Precisamente por eso se prevé también que «en la medida en que la presente Carta reconozca derechos fundamentales resultantes de las tradiciones constitucionales comunes a los Estados miembros, dichos derechos se interpretarán en armonía con las citadas tradiciones» (art. 52.4). Bien es cierto que, como muestran los asuntos Melloni y Akerberg, no siempre será tarea sencilla articular en la práctica la tarea de interpretación 'en armonía' con esas tradiciones constitucionales.

Ahora bien, no puede olvidarse que el puzle de la protección de los derechos en el ámbito de la Unión tiene en el sistema diseñado por el Tratado de Lisboa 
una pieza añadida cuya función es precisamente someter la actuación de la Unión y del propio TJUE al control judicial externo que en materia de derechos fundamentales tiene encomendando el TEDH. Tal tarea es la que encarna el artículo 6.2 TUE al cerrar una discusión doctrinal que duraba ya décadas y establecer con toda rotundidad que la «Unión se adherirá al Convenio Europeo para la Protección de los Derechos Humanos y de las Libertades Fundamentales» (cursiva añadida por nosotros). Sin embargo, el TJUE ha cerrado el camino a esa adhesión al establecer en su dictamen 2/2013 que el proyecto de Acuerdo de adhesión negociado al efecto era contrario al Derecho de la Unión. Con ello se dinamita un elemento esencial para el equilibrio y sistematicidad de la protección multinivel de los derechos fundamentales en el espacio jurídico europeo.

Finalmente, por lo que respecta a la pregunta de si el TJUE ha devenido en un factor de la constitucionalidad de los Estados miembros, la respuesta ha de formularse indefectiblemente en sentido afirmativo. Parece claro que la doctrina del TJUE tiene una incidencia directa en las constituciones nacionales; se está produciendo una europeización evidente de las Constituciones nacionales, a la vez que la jurisprudencia del TJUE se ha visto influenciada por los Tribunales Constitucionales, especialmente por el alemán. Ello ha resultado evidente en el importante ámbito de los derechos fundamentales a través de la bien conocida doctrina Solange, pero también se está dando en otros campos, cobrando en este momento un papel esencial la concreción del concepto de 'identidad constitucional', tanto desde la dimensión de la Unión al interpretar el alcance del artículo 4.2 TUE, como desde la de la de los Estados miembros al fijar sus Tribunales Constitucionales los límites a las atribuciones competenciales realizadas a favor de la Unión a través de las respectivas cláusulas europeas, en nuestro caso a través de la Declaración 1/2004.

Sea como fuere, una conclusión final de estas sugerentes preguntas es evidente: nos encontramos ante una nueva y apasionante dimensión jurídica que con toda probabilidad nos ocupará tanto a constitucionalistas como a internacionalistas durante bastante tiempo.

\section{JAVIER MATÍA PORTILLA}

Realmente, esta pregunta es muy compleja y plantea diversas cuestiones concretas. Trataremos de dar una breve opinión personal sobre cada una de ellas, aunque ya adelantamos que para ello también será preciso, en ocasiones, contextualizarlas.

El primer interrogante que se nos plantea es si estimamos que la Unión, al ser garante de los derechos fundamentales, avanza o no efectivamente en la creación de un espacio común de protección de los derechos. Aunque podría ser que la pregunte se vincule con la concreta introducción de la Carta de Niza en los Tratados de la Unión, conviene recordar que la Unión Europea ha hecho mucho 
por avanzar en una cultura constitucional, en la medida en que ha fomentado la democracia dentro y fuera de sus fronteras y ha luchado también porque los Estados europeos garantizaran la libertad de sus ciudadanos y justiciables.

Podría afirmarse que desde la Unión Europea se ha impulsado una política de derechos humanos (Rubio) que ha supuesto para algunos Estados candidatos (España ha sido uno de ellos) la obligación de consolidar las estructuras propias de los Estados democráticos y de Derecho. Y esa labor se ha extendido también a través de los programas de cooperación (en Europa Central y Oriental, África, Caribe y Pacífico - ACP_-, América latina y Asia).

Además de esa política que trata de exportar e influir cultura constitucional, debemos recordar que el Tribunal de Justicia de las Comunidades Europeas determinó, en la difundida Sentencia Stauder que los derechos fundamentales se encontraban recogidos en los principios generales del Derecho Comunitario y que las Instituciones comunitarias y los Estados miembros debían respetarlos cuando actuaran en el marco del Derecho de la Unión. En ese primer momento, el Tribunal de Luxemburgo dio pruebas de inteligencia y de buen sentido, que ha retomado con posterioridad. Así, por ejemplo, haciendo ver al Consejo de Ministros de la Unión Europea que la Carta podía ser tomada en consideración porque se limita —en palabras de las Comisión Europea- a hacer visibles los derechos preexistentes, pese a no haber sido incorporada formalmente a los Tratados (STJUE — Gran Sala— de 27 de junio de 2006, C-540/03).

$\mathrm{Si}$ al Tribunal de Justicia le corresponde el mérito de haber introducido los derechos fundamentales en el ordenamiento jurídico de la Unión, la Comisión Europea tiene el honor de haber perseverado en la adhesión de la Unión Europea al Convenio Europeo de Derechos Humanos.

Si bien todos estos datos podrían invitar al optimismo, existen otros datos que también hay que recordar, y que nos llevan hacia un pesimismo moderado.

Desde una perspectiva general, por la limitada ambición con la que el Tribunal de Justicia se dedica a amparar los derechos fundamentales de la Carta. Son muy pocas las ocasiones en que ha censurado el comportamiento de las Instituciones de la Unión, y muchas de sus resoluciones revelan una escasa sensibilidad hacia los derechos humanos, como acredita la citada STJUE Melloni, a la que ya se ha hecho amplia referencia en líneas anteriores.

Tal actuación podría ser admisible si el Tribunal de Luxemburgo hubiera facilitado la vinculación formal de la Unión al Convenio Europeo de Derechos Humanos (se dice formal porque, a nuestro juicio, dicha vinculación ya existe en la medida en que compromete actuaciones de los Estados miembros que deben respetar, en todo caso — - esto es, también cuando aplican el Derecho de la Unión-, el Convenio). Pero como también se ha indicado su actuación en este punto ha sido bastante desacertada, tanto en la forma como en el fondo.

También se indicó que esta maniobra podría ser desactivada con facilidad si los Gobiernos de los Estados miembros quisieran. Pero no parece que los vientos políticos vayan en esa dirección. Las pretensiones perseguidas con el tratado de 
Maastricht, de ahondar en una unidad monetaria y política (ésta última, por cierto, a instancias del Gobierno español), tuvieron un muy corto recorrido. En los últimos años hemos observado cómo los Estados miembros han optado por sobredimensionar su actuación internacional en relación con la realizada en el seno de la Unión Europea, evitando, así, el control del Tribunal de Luxemburgo; hemos sido testigos de un mínimo compromiso con los refugiados; y hemos tenido la oportunidad de comprobar que están más preocupados por el crecimiento de los mercados y por reforzar la seguridad que por la protección de los derechos humanos. Resulta paradójico que hoy sea más eficiente la protección deparada por el Tribunal de Estrasburgo que la dispensada por el de Luxemburgo, cuando es la propia Unión la que exige que los Estados candidatos se adhieran al Convenio Europeo de Derechos Humanos.

Es claro que estas carencias pueden ser superadas. Como ya se ha indicado, algunas recientes Sentencias del Tribunal de Justicia sobre la orden europea de detención y entrega han matizado el rigor mostrado en Melloni. Y no resulta imposible que surjan líderes europeos que tengan la ambición y la capacidad suficientes para avanzar en el proceso de integración europea, rememorando la dorada época de Mitterrand, Kohl y González en los Gobiernos estatales y Delors en la Presidencia de la Comisión.

La segunda cuestión que se nos plantea es si la Unión Europea ha incorporado en su estructura — el TJUE incluido- un factor de expansividad competencial al que será muy difícil poner otro límite que el que autoadapten el TJUE y las restantes instituciones de la propia Unión Europea.

Si una obsesión acompaña a los autores de la Carta de los derechos fundamentales de la Unión Europea es señalar una y otra vez que ésta vincula exclusivamente «dentro de los límites de las competencias que los Tratados atribuyen a la Unión» (art. 52.1 CDFUE), sin ampliar «el ámbito de aplicación del Derecho de la Unión más allá de las competencias de la Unión» (art. 52.2 CDFUE) (ver también el artículo 6.1 TUE, la Declaración de la CIG sobre la Carta, el Preámbulo y los artículos 51.1, 51.2 y 52.5 de la Carta).

Esta idea contrasta con la tesis de que muchos derechos fundamentales exigen, para su efectividad, ser desarrollados a través de normas jurídicas. Por eso es legítimo pensar que los derechos fundamentales pueden servir para, si no ampliar, si enriquecer las (ya muy amplias) competencias de la Unión (Biglino).

Se nos inquiere, finalmente, sobre si el Tribunal de Luxemburgo se ha convertido en un factor de la constitucionalidad de los Estados miembros. Para dar respuesta a este interrogante sería preciso determinar, previamente, que debe entenderse por «factor de la constitucionalidad».

Si por tal término se entiende, en primer lugar, que nuestra implicación en la Unión puede servir para conservar y mejorar nuestro Estado constitucional, la respuesta debe ser decididamente positiva.

De un lado porque, como ya se ha indicado, nuestra pretensión de formar parte de las Comunidades Europeas nos ha obligado a optar por un modelo 
decididamente democrático y por un Estado de derecho que privilegie la posición de los derechos fundamentales y humanos. Aunque es probable que el Estado español hubiera optado por sí mismo por adherirse al Convenio Europeo de Derechos Humanos, esta era también una de las exigencias impuestas por nuestros futuros socios europeos.

De otro, porque nuestra implicación en la Unión Europea dificulta (afortunadamente) el surgimiento de movimientos populistas dentro de nuestras fronteras, o el ataque a las estructura liberal de nuestra economía. Y este dato no debe minusvalorarse, porque la libertad económica resulta esencial para cualquier Estado constitucional que se precie. En este sentido resulta reconfortante la existencia del artículo 7 TUE y de la Comunicación de la Comisión sobre Un nuevo marco de la UE para reforzar el Estado de Derecho - COM (2014) 158-, que ha dado lugar a la reciente Recomendación en la que se da un plazo (finalmente prorrogado) al Gobierno polaco para que su reforma del Tribunal Constitucional no cuestione el Estado de Derecho — Recomendación (UE) 2016/1374 de la Comisión, de 27 de julio de 2016, relativa al Estado de Derecho de Polonia-.

Pero por «factor de constitucionalidad» se puede entender, en segundo lugar, que la interpretación de nuestra Constitución no puede realizarse al margen de la jurisprudencia dictada por el Tribunal de Justicia de la Unión Europea. Y si se interpreta así dicho término, la respuesta que debe darse al interrogante planteado es negativa.

Antes de explicar el porqué de esta opinión, es oportuno señalar que la Unión Europea puede ser útil para mejorar nuestros derechos fundamentales y humanos, como acreditan las recientes SSTJUE (Sala Décima) de 14 de septiembre de 2016, C-596/14 (derecho de los trabajadores por tiempo determinado a recibir una indemnización por despido equivalente a la fijada para los trabajadores fijos comparables) y (Gran Sala) de 21 de diciembre de 2016, C-154/15, C-307/15 y C-308/15 (efecto pleno de la nulidad, por abusivas, de las cláusulas suelos en las hipotecas españolas).

Estas resoluciones favorecen una mejor aplicación de nuestros derechos fundamentales, y se imponen además en su aplicación en virtud de la primacía del Derecho de la Unión, pero no limitan (no podrían hacerlo) las interpretaciones más extensivas de los derechos fundamentales (en general, de los preceptos constitucionales) que pueda ofrecer nuestro Tribunal Constitucional, y que se deriva del lugar que ocupan los Tratados internacionales en el sistema de fuentes y de la función constitucional que cumple la Carta de los Derechos Fundamentales de la Unión (como ya hemos explicado, con más detalle, en la preguntas 3 y 4).

Dicho esto, sería deseable que tal activismo judicial del Tribunal de Justicia afectara a otros derechos más relevantes (como son los vinculados con las garantías procesales y determinados derechos sustantivos) y que sirvieran para controlar más intensamente la actuación de las Instituciones de la Unión (y no solamente de los Estados miembros). Por esta razón debemos alegrarnos de las SSTJUE, relacionadas con la orden europea de detención y entrega, a las que hemos hecho expresa 
referencia en la pregunta 4 de la presente encuesta. Es oportuno recordar que existen algunas resoluciones del Tribunal de Luxemburgo que han mostrado su voluntad en la defensa de los derechos fundamentales (entre las que destacaríamos, además de las clásicas de los años 1969, 1970 y 1974 y 2006, a la que se ha hecho referencia supra, en esta misma cuestión). Ojalá que sean estas resoluciones las que guíen el futuro comportamiento del Tribunal de Luxemburgo, contribuyendo así al afianzamiento de la cultura constitucional dentro y fuera de la Unión.

\section{JUAN LUIS REQUEJO PAGÉS}

El ámbito de los derechos fundamentales tiene una potencialidad expansiva extraordinaria, pues su objeto es la relación del individuo con el poder público en todas las dimensiones de su vida personal, social, política, económica y cultural. La competencia conferida formalmente a la Unión en ese ámbito en virtud de la Carta de Niza permite a las instituciones sobreponerse a su condición de titulares de competencias atribuidas y tasadas. Por esa vía la Unión puede avanzar muy significativamente en su lucha por la soberanía.

La doctrina Melloni/Akerberg Fransson es la mejor prueba de que el Tribunal de Justicia no dejará pasar la ocasión de apurar los límites de la Unión hasta el extremo de lo permitido por los Tratados... y un poco más allá, ganando para sí un terreno al que difícilmente podría acceder sin el auxilio de la Carta. Tomando pie en su competencia en materia de IVA, con Akerberg Fransson el Tribunal de Justicia se ha hecho con la palabra en el ámbito de los principios de la legalidad penal. Es una vía abierta a la que pueden seguir tantas cuantas el Tribunal de Justicia se aventure a franquear. Lo hará en la medida en que perciba que los Estados miembros (sus Tribunales Constitucionales o equivalentes) están dispuestos a consentírselo. Pero así ha sido siempre en la historia de la construcción europea, que es la de una confrontación de poderes cuyos avances y retrocesos responden a una estrategia basada en el cálculo cuidadoso de las fuerzas propias y ajenas.

Es evidente que la Carta supone un avance en la creación de un espacio común de protección de los derechos fundamentales. La cuestión es si no se están construyendo demasiados espacios. Al espacio constitucional se añade ahora el de la Unión, sumando tres con el del Convenio Europeo de Derechos Fundamentales. La articulación de esos tres espacios corresponde a tres órdenes jurisdiccionales: el Tribunal de Justicia, el Tribunal de Estrasburgo y las jurisdicciones nacionales; estas últimas, en su totalidad y sin exclusión, aunque a los Tribunales Constitucionales les cumpla un papel cualificado. El hecho de que el Tribunal de Justicia se resista a autorizar la adhesión de la Unión al Convenio de Roma supone una grave dificultad para que esa articulación sea viable y eficaz. Pero, aun en el caso de que la adhesión se produzca, quedará siempre la dificultad que implica la existencia de una pluralidad de enunciados de derechos cuyo contenido, más allá de su identidad formal, será distinto en función de la jurisdicción ante la que se 
pretenda su protección. Pertrechado con derechos que se disputan de manera concurrente la garantía de todas las dimensiones de su personalidad y de todas las variables de su conducta, el individuo puede acabar en el caso de no tener quien le proteja.

TITLE: Academic survey about the European Court of Justice as a constitutional actor

ABSTRACT: In this academic survey a group of Constitutional Law Professors answer some questions about the role of the European Court of Justice as a constitutional actor, especially when a national constitutional court raises a preliminary ruling before the Court of Justice of the European Union, and its consequences in the traditional constitutional order.

Resumen: En esta encuesta un grupo de Catedráticos de Derecho Constitucional contestan un conjunto de preguntas sobre el rol del Tribunal de Justicia de la Unión Europea como actor de la constitucionalidad, especialmente en los casos en los que un Tribunal Constitucional nacional presenta una cuestión prejudicial ante el Tribunal de Justicia de la Unión Europea, y las consecuencias que ello trae consigo en el orden constitucional tradicionalmente vinculado al Estado nacional soberano.

KeY wORDs: Court of Justice of the European Union, Constitutional Court, Preliminary rulings, Case Melloni.

Palabras Clave: Tribunal de Justicia de la Unión Europea, Tribunal Constitucional, Cuestión prejudicial, Caso Melloni. 